Wesley, D. A., G. Poulos, J. Snook, P. Kennedy, M. Meyers, and G. Byrd, 2013: Extreme snowfall variations and cold-air damming in the Front Range heavy snowstorm of 17-19 March 2003. J. Operational Meteor., 1 (4), 26-51, doi: http://dx.doi.org/10.15191/nwajom.2013.0104.

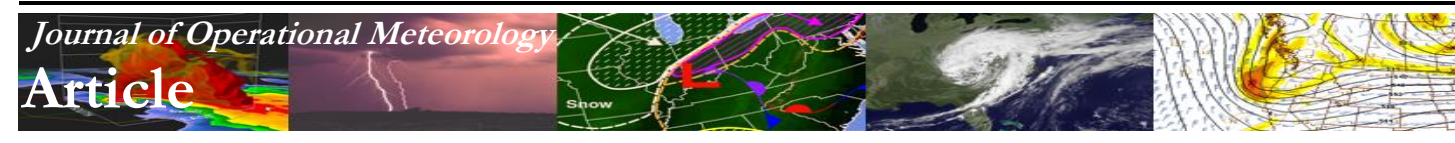

\title{
Extreme Snowfall Variations and Cold-Air Damming in the Front Range Heavy Snowstorm of 17-19 March 2003
}

\author{
DOUGLAS A. WESLEY \\ Compass Energies, Denver, Colorado \\ GREG POULOS \\ V-Bar, LLC, Golden, Colorado \\ JOHN SNOOK \\ Colorado Avalanche Information Center, Boulder, Colorado \\ PAT KENNEDY \\ Colorado State University, Fort Collins, Colorado \\ MIKE MEYERS \\ NOAA/National Weather Service, Grand Junction, Colorado \\ GREG BYRD \\ Cooperative Program for Operational Meteorology, Education and Training, UCAR, Boulder, Colorado
}

(Manuscript received 26 September 2011; in final form 21 April 2012)

\begin{abstract}
This study examines the dynamics and thermodynamics associated with the climatologically extraordinary 17-19 March 2003 snowstorm that impacted the Colorado Front Range and some surrounding areas. In particular, several anomalously high local snowfall gradients are examined to improve our understanding of precipitation distributions associated with upslope flow, blocking, and cold-air damming. This unusual event was established as a result of a deep, slowly propagating closed low. The continental-scale closed low was characterized by persistent strong upslope (or easterly) flow that transported large amounts of moisture into the Colorado Rocky Mountain barrier. Warm easterly inflow well above freezing was blocked by the terrain, and this soon created a barrier jet-like feature over the urban corridor. Simultaneously, lowlevel cold advection from the north occurred over the east side of the barrier due to larger-scale processes, a situation not associated with a classic barrier jet. Nevertheless, subsequently the warm inflow was lifted over the cold dome. A fourth important process, diabatic cooling from melting hydrometeors, contributed strongly to the cold dome and generated a nearly isothermal low-level temperature profile. Both cooling mechanisms (advection and diabatic) were significant. Resulting temperatures just east of the foothills were at or very close to the freezing point as the heavy snow event occurred. Precipitation type and snowfall density were major contributors to the heterogeneity of the precipitation distribution.

The roles of cold-air damming and barrier jet-like features as the driving forces in both the dynamics and thermodynamics of the storm along the urban corridor are described in detail using radar, surface, and high-resolution nested model data from the Pennsylvania State University-National Center for Atmospheric Research fifth-generation Mesoscale Model. The dammed cold air, centered over and just east of the foothills, was sloped laterally upwards towards the high terrain to the west, and topped by a stable, strongly sheared layer. This dynamic setup produced heavy precipitation away from the steep terrain gradient. Heavy precipitation rates played a major role in the development of a persistent rain/snow boundary well east on the plains. The northerly flow within the cold air also generated some local downslope flow, leading to areas of drastically reduced snowfall even when compared to that of lower elevations to the east.
\end{abstract}

Corresponding author address: Douglas A. Wesley, Compass Energies, 515 30th St., Unit A, Denver, CO 80205

E-mail: wesley1snowstorm@gmail.com 


\section{Introduction}

During the period 17-19 March 2003, a climatologically anomalous snowstorm crippled the central and southern Rocky Mountain and high plains regions of the western and central United States (Doesken 2003), including the greater metropolitan Denver area. Figure 1 shows a plot of the general total estimated snowfall, based on official and public reports [see Doesken (2003) and Weaver (2003) for more detailed storm snowfall observations and public impacts]. Weaver (2004) and Wilson (2003) stated that this storm produced the second largest snowfall in the history of record for the northern Front Range. At the Stapleton Airport site, this was the heaviest snowfall in over 60 years, as reported by the National Oceanic and Atmospheric Administration (NOAA) National Weather Service (NWS) in Boulder. Record amounts of snowfall even extended to just west of the Continental Divide at the Winter Park ski area.

As one would expect, impacts from this severe snowstorm were profound and included:

- over $\$ 100$ million in insurance claims related to vehicular and structural damage, resulting in the highest nationwide insured losses for the entire first quarter of 2003 (Weaver 2003);

- several thousand travelers stranded at Denver International Airport, which closed for almost two days; skiers snowbound at both eastern and western slope Colorado ski resorts for more than two days; and residents stranded for 5-7 days in many foothill locations (Doesken 2003);

- a large number of collapsed public structures and numerous major power failures;

- crippled highway travel for more than two days, including interstate highway system closures in an area where two interstate highways intersect;

- and, a pronounced mitigating effect on an ongoing severe drought in the region; specifically, this storm essentially ended the drought locally (at least temporarily) in many eastern-slope mountain and foothill locations in Colorado (Doesken 2003).

As previously shown in Fig. 1, more than $1.5 \mathrm{~m}$ (5 $\mathrm{ft}$ ) of snowfall covered a significant portion of the Front Range of north-central Colorado, generally over and east of the Continental Divide (a sample photograph is shown in Fig. 2). The heaviest snowfall was concentrated in the foothills east of the Continental Divide at elevations of $2135 \mathrm{~m}(7000 \mathrm{ft})$

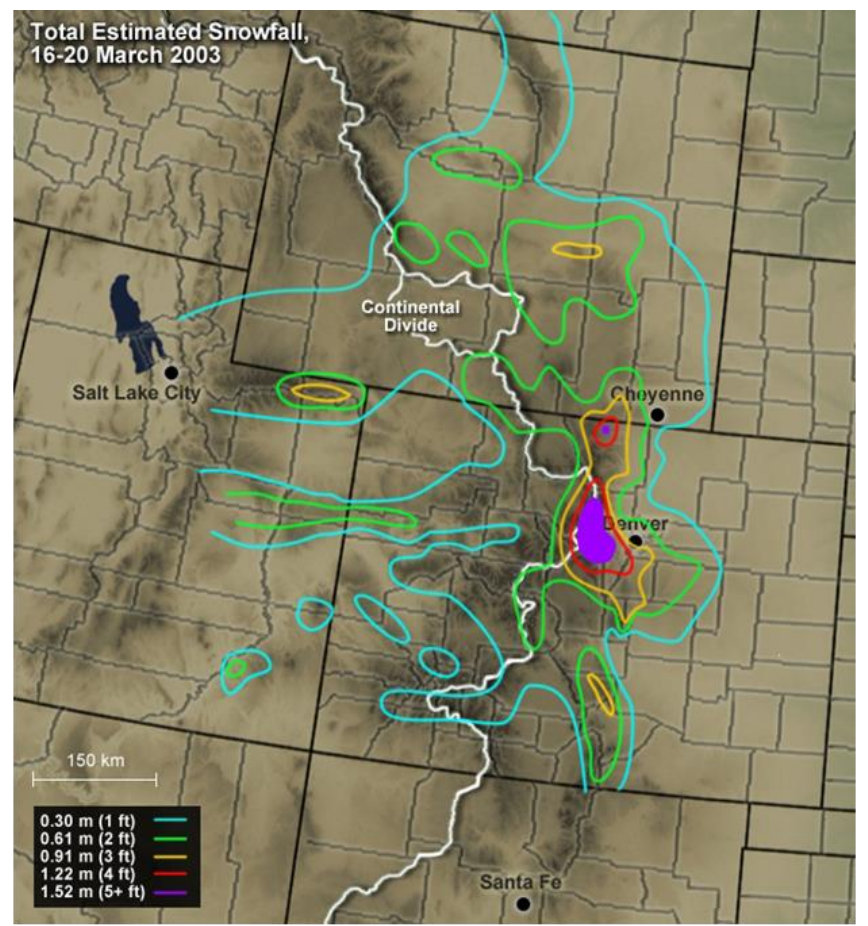

Figure 1. Total estimated snowfall $(\mathrm{m})$ in the central Rocky Mountain region for the period 17-19 March 2003. Purple-shaded areas represent $>1.5 \mathrm{~m}$ of accumulation. A snow depth of $1 \mathrm{~m}$ corresponds to 39.4 in. Click image for an external version; this applies to all figures hereafter.

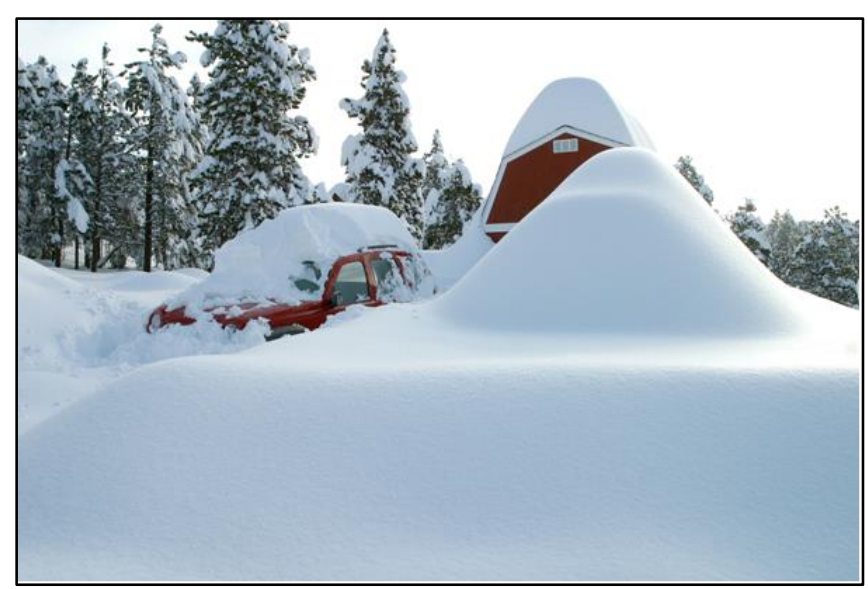

Figure 2. Post-storm photograph near Nederland, CO, at an elevation of approximately $2590 \mathrm{~m}(8500 \mathrm{ft})$, courtesy of Carlye Calvin (UCAR). A vehicle on the right side of the photograph is completely buried in fresh snow.

and upwards; the east side was the "upslope" side of the Divide in this storm. A more detailed precipitation analysis (Fig. 3a) was made possible through the utilization of the Community Collaborative Rain and Hail Study [CoCoRaHS, www.cocorahs.org, a volunteer-based precipitation observation network organized and maintained by Colorado State 

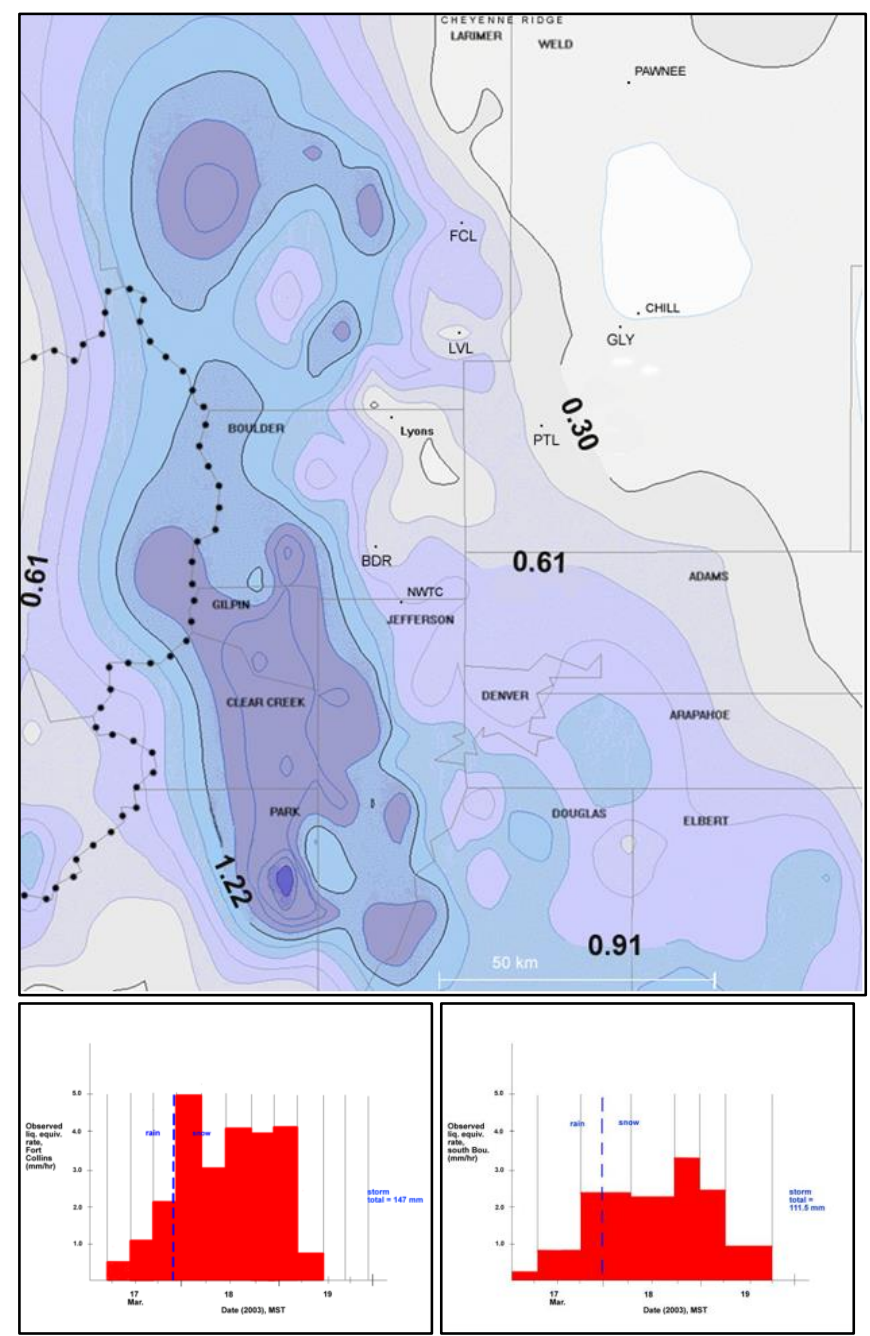

Figure 3. (a, top) Objective analysis for the total observed snowfall $(\mathrm{m})$ for the north-central area of $\mathrm{CO}$, centered on the foothills west of Denver, 16-19 March 2003. County boundaries are shown as thin grey lines. Contour interval is $0.15 \mathrm{~m}$. Locations shown are as follows: BDR (Boulder), CHILL radar site, PAWNEE radar site, FCL (Fort Collins), GLY (Greeley), LVL (Loveland), Lyons, NWTC (National Wind Technology Center), and PTL (Platteville). Dotted line is the Continental Divide. See text for snowfall data sources. A snow depth of $1 \mathrm{~m}$ corresponds to 39.4 in. Liquid precipitation rate measurements for the storm at (b, lower left) Fort Collins and (c, lower right) Boulder, CO. The vertical blue dashed line denotes the rain-to-snow transition late on 17 March. $1 \mathrm{~mm}$ of precipitation corresponds to $0.04 \mathrm{in}$.

University (CSU)], the National Weather Service Cooperative Network, and other unofficial reports such as those from ski areas.

Interpretation of these observations is facilitated when one simultaneously views the details of the terrain in this region, shown in Fig. 4. Generally speaking, the heaviest snow fell over the steepest eastern-facing slopes of the Front Range, stretching from near the Continental Divide eastward to the

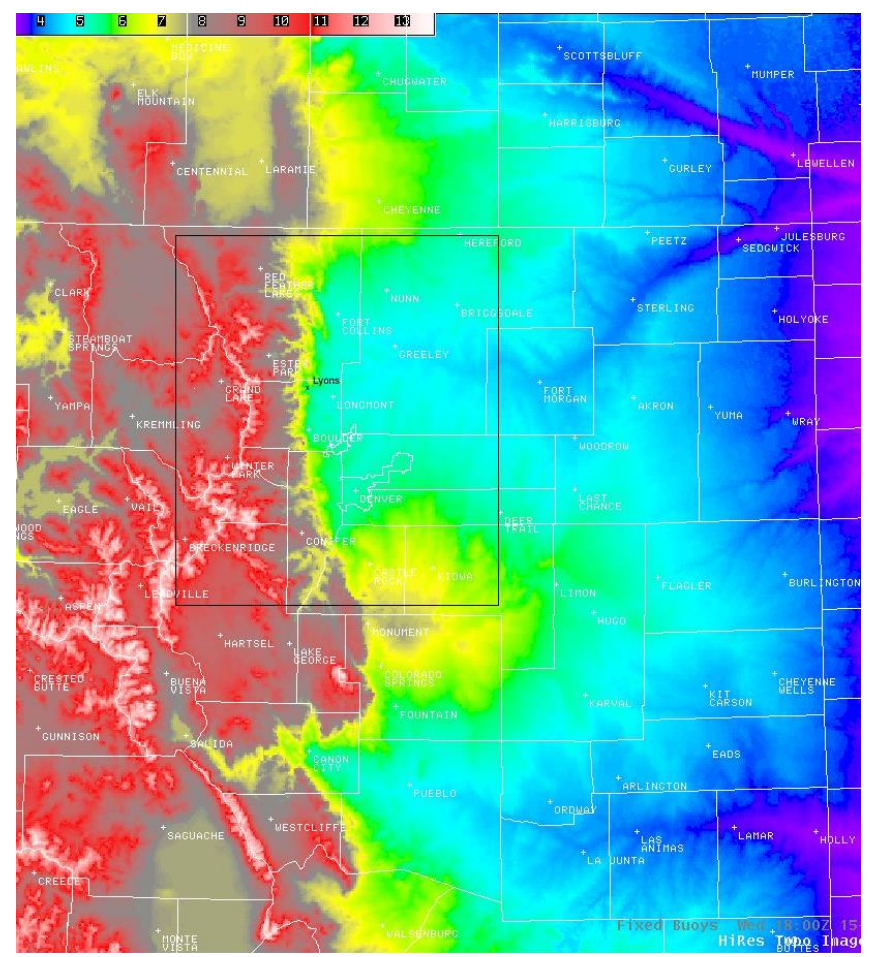

Figure 4. High-resolution topography over northeastern CO, utilizing NOAA/NWS Advanced Weather Interactive Processing System (AWIPS) elevation data. Color coding is shown in increments of approximately $300 \mathrm{~m}$ (or in thousands of feet) ranging from above $3660 \mathrm{~m}$ (12,000 feet) in pink to below $1220 \mathrm{~m}$ (4000 feet) in magenta; see the scale at the upper left corner. The Lyons location is shown; see Fig. 3a for other city and measurement locations. The rectangular region outlined in black lines corresponds to the region analyzed in Fig. 3a.

approximate $1615-\mathrm{m}$ (5300-ft) elevation contour, and from just north of the Wyoming/Colorado border southward to the higher terrain south and west of Denver. An extended area in the foothills experienced

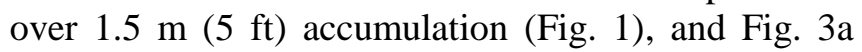
also shows that extensive urban regions received over $0.6 \mathrm{~m}(2 \mathrm{ft})$ of snow. Very large gradients in snow depth over small horizontal distances were common, especially in eastern Boulder and Larimer Counties.

Focusing on the urban corridor [the heavily populated Interstate-25 (I-25) corridor extending from Cheyenne, Wyoming, southward to the Colorado Springs, Colorado, area], very large snowfall variations occurred on spatial scales of $10 \mathrm{~km}$ or less, and the snowfall accumulation was not directly associated with elevation in many regions. In fact, some intriguing snowfall minima occurred at elevations comparable to those that received very deep snows (e.g., in and around the town of Lyons in northeastern Boulder County and Loveland in southeastern Larimer County). This storm's intense 
gradients in snowfall presented serious challenges to operational forecasters, and are one of the emphases of this study. Given the synoptic enormity of this system, an essential question is how could such hypergradients develop within areas of similar elevation?

Placing all into a historical perspective, the 17-19 March 2003 storm ranks second for severe Colorado snowstorms, which includes other severe storms such as the December 1913 event (Doesken 2003). As Doesken stated, "The snowstorm of December 1-5, 1913 seemed unsurpassable, yet the March 2003 storm dropped more water in less time in several areas of the Front Range." Figures $3 \mathrm{~b}-\mathrm{c}$ show two examples of liquid equivalent rates [totaling $10-15 \mathrm{~cm}$ (4-6 in)] through the storm at two urban Front Range locations (Fort Collins and Boulder) with elevations just over $1.5 \mathrm{~km}(4921 \mathrm{ft})$.

Continuing with an overview of historical severe snowstorms in the Front Range, Marwitz and Toth (1993) analyzed another Front Range storm from 3-5 March 1990 that exhibited some similarities from a dynamic standpoint to the 2003 event. Both events were warm enough to produce rain initially in the urban corridor, but a changeover to snow soon occurred and was permanent; a significant, persistent rain/snow line set up east of the north-south-oriented highway I-25. Cold-air damming (Schwerdtfeger 1974, 1975; Richwien 1980; Dunn 1987; Forbes et al. 1987; Fritsch et al. 1992; Bousquet and Smull 2003; and Cox et al. 2005) in the 2003 case manifested itself as a mesoscale frontal zone and was a major factor in the precipitation types and distribution, as documented in Marwitz and Toth (1993). Winds in the dammed layer were predominantly north-to-south and resembled in some ways a barrier jet. Diabatic processes were also shown to be a large factor in the development of cold air within the dammed region. Apart from these similarities, the 2003 storm exhibited significant differences from the 1990 event including: 1) significant low-level cold advection; 2) greater snowfall in the Denver/Boulder region, the adjacent foothills, and Palmer Divide region to the south; and 3) a deeper (well over $1 \mathrm{~km}$ ) blocked layer.

Poulos et al. (2002) and Meyers et al. (2003) studied an additional intense snow and wind storm that also had major public impacts on the central Rockies and Front Range on 24-25 October 1997. This highly dynamic but faster-moving storm left $0.6 \mathrm{~m}(2 \mathrm{ft})$ or more of accumulation in the higher terrain and the eastern Colorado foothills, and thousands of acres of downed timber west of the Continental Divide near
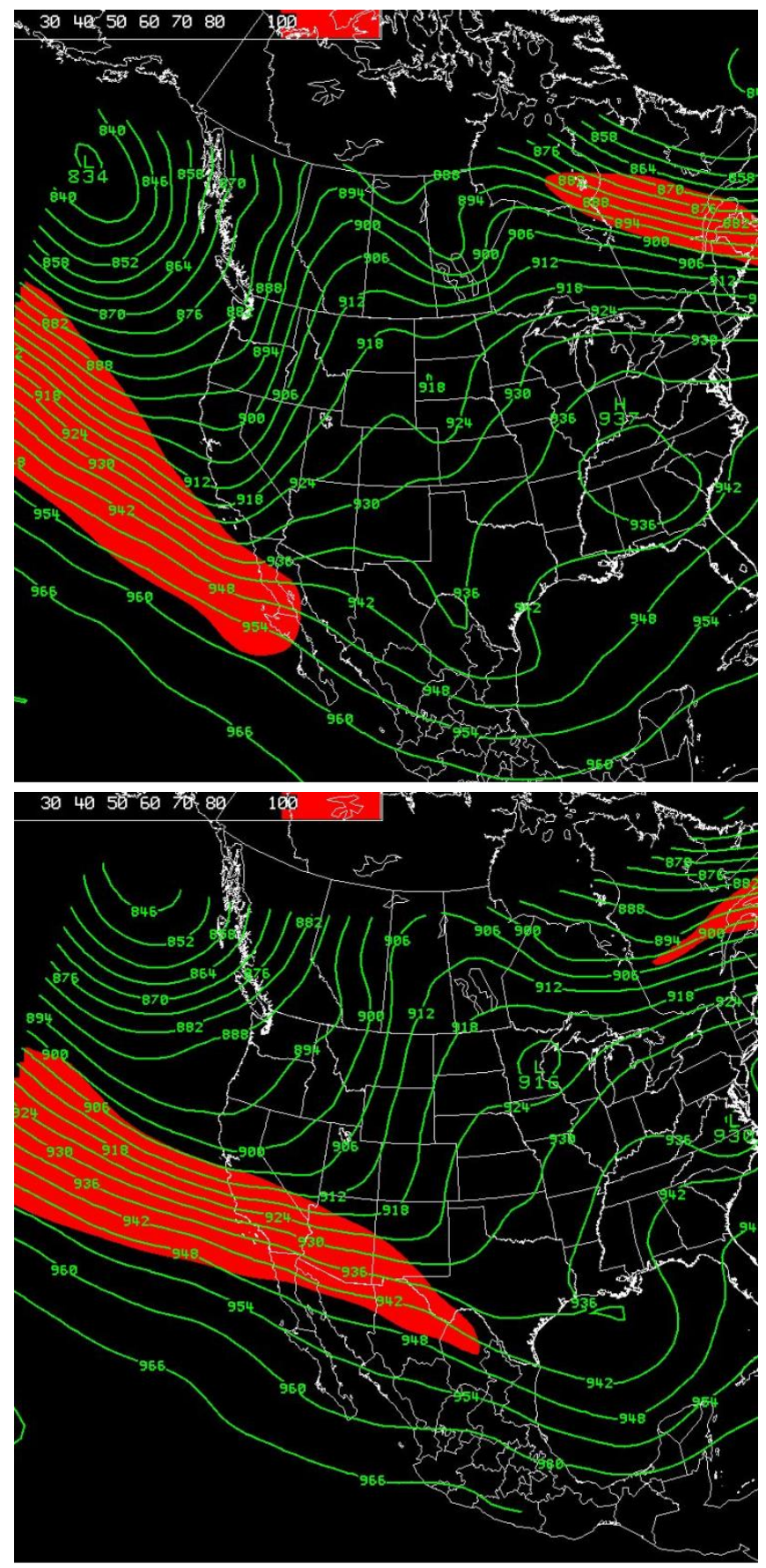

Figure 5. Eta-analyzed 300-mb heights (m) valid (a, top) 0000 UTC 16 March 2003 and (b, bottom) 0000 UTC 17 March 2003. Red-shaded regions depict wind speeds $>51 \mathrm{~m} \mathrm{~s}^{-1}(100 \mathrm{kt})$.

Steamboat Springs. Forced by an intensely digging (and eventually closed) circulation aloft and strong advection of low-level Canadian air southward down the Front Range, this storm spanned a much shorter time period than the 2003 event and did not produce significant rainfall over the central high plains due to colder temperatures. However, strong variability in 

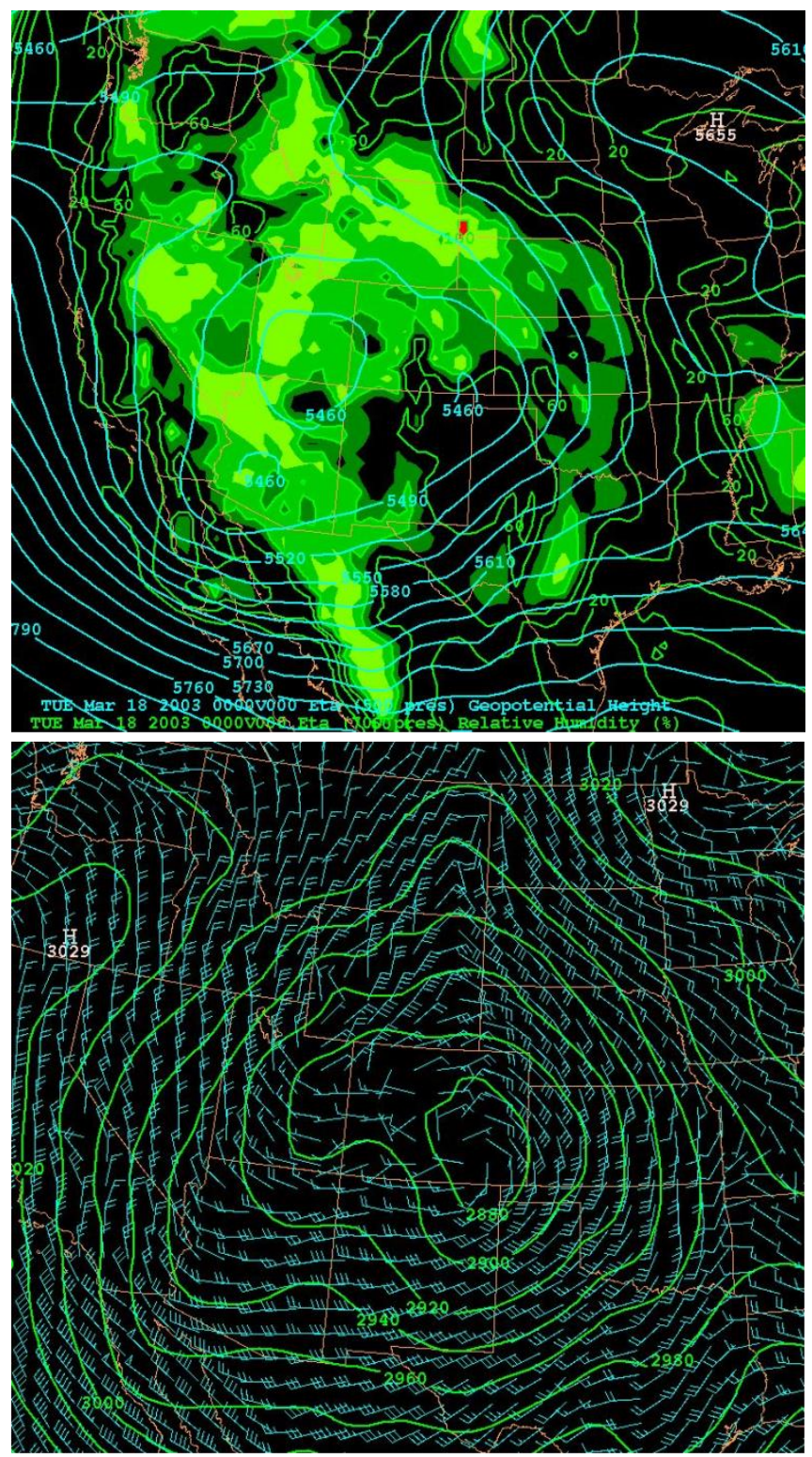

Figure 6. (a, top) Eta-analyzed 500-mb height (m) and 700-mb relative humidity $(\mathrm{RH}, \%)$ at 0000 UTC 18 March 2003. RH values above $70 \%$ are shaded in green. (b, bottom) Eta-analyzed 700-mb heights (m) and wind (kt) at 0000 UTC 18 March 2003.

snowfall accumulation, related to the complex terrain, also was present.

The snowfall accumulations along the urban corridor for 17-19 March 2003 were strongly influenced by the thermodynamic structure. Surface temperatures at or very close to freezing were persistently observed at elevations of $1370 \mathrm{~m}(4500 \mathrm{ft})$ to $1870 \mathrm{~m}(6000 \mathrm{ft})$ in some of the hardest-hit regions. A large degree of melting was occurring during the early stages of the storm in all areas at or below 1870 $\mathrm{m}(6000 \mathrm{ft})$ in elevation. Thus, snow depths were critically dependent on local thermodynamics. The melting/cooling influence enabled areas of heavy snowfall to subsequently occur where perhaps, synoptically, rain would have been favored [also see Marwitz and Toth (1993) and Bailey et al. (2003)]. Of interest, upright convection contributed significantly to heavy precipitation, especially early in the storm.

The complex structure in low-level temperature fields in the severe 2003 snowstorm appeared to play a major role in the determination not only of precipitation type, but also snowfall density. Slightly warmer regions in the urban corridor received snowfall that was markedly higher in density, and this was a significant factor in determining final accumulations. The low-level thermal structure was in part determined by local terrain features. Mesoscale model simulations of the storm have aided in specifying the impact of these features on local temperatures, and the subsequent influence on snow accumulation rates.

The mesoscale dynamics and thermodynamics of the 2003 storm will be investigated to infer the primary causes of the meso- $\gamma$-scale variations in snowfall. This paper will first present an overview of this historic event from a synoptic-scale standpoint. Then, storm characteristics that presented critical forecast challenges in terms of large horizontal gradients of snowfall will be discussed in detail, utilizing both observations of the storm in sections 3 and mesoscale model simulations in section 4 .

\section{Synoptic overview}

During the period 15-17 March, a strong negatively tilted trough amplified as it built into the central and southern Rockies. A strong 300-mb jet moving into the southwestern United States coast from the central and northern Pacific greatly influenced the amplification of this trough (Fig. 5) ${ }^{\mathbf{1}}$. Downstream ridge amplification resulted over the eastern United States, thereby creating a favorable environment for the transport of Gulf of Mexico moisture into the high plains and Rockies. By 0000 UTC 18 March, the large and deep trough became well organized over the southern Rockies and continued to amplify (Fig. 6). The 500-mb low center was over southern Utah (Fig. $6 a)$, with the associated cyclonic circulation extending outward to northern Nevada, southern Arizona,

\footnotetext{
1 This and all subsequent "Eta" analyses and predictions refer to the National Center for Environmental Prediction (NCEP) 12-km Eta operational model (Black 1994; i.e., pre-WRF), with the model output plotted at $20-\mathrm{km}$ grid spacing.
} 

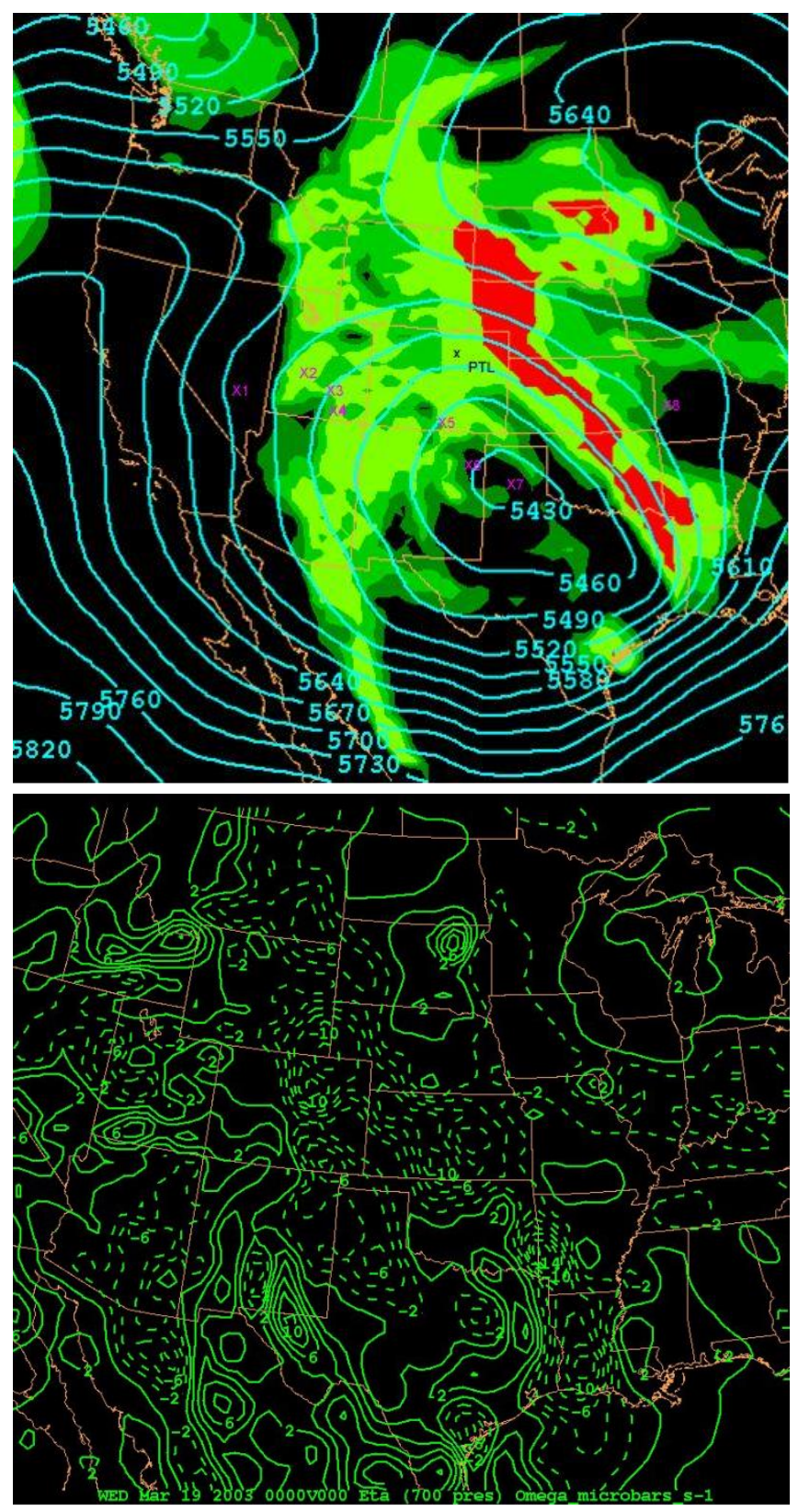

Figure 7. (a, top) Eta-analyzed 500-mb height (m) and 700-mb RH (\%) at 0000 UTC 19 March 2003. Shading for RH is the same as in Fig. 6. The strong warm conveyor belt extended from eastern TX northwestward into the central high plains and northeastern $\mathrm{CO}$ at this time. Purple Xs (1-8) represent successive positions of the primary center of the Eta-analyzed $500-\mathrm{mb}$ closed low at the following times: (1) 0000 UTC 17 March, (2) 1200 UTC 17 March, (3)1800 UTC 17 March, (4) 0000 UTC 18 March, (5) 0600 UTC 18 March, (6) 1200 UTC 18 March, (7) 0000 UTC 19 March, and (8) 1200 UTC 19 March. (b, bottom) Eta-analyzed 700-mb omega ( $\mu \mathrm{b} \mathrm{s}^{-1}$, dashed negative) at 0000 UTC 19 March 2003.

western Kansas, and central Wyoming. Deep and moist upslope flow thereby became established over the northern Front Range of the Rockies and adjoining central/high plains. The 700-mb height analysis (Fig. $6 \mathrm{~b})$ showed the closed low position over southeastern Colorado with 10-21 m s $\mathrm{m}^{-1}$ (20-40 kt) of cyclonic flow wrapping up around the east side of the low. Easterly flow at $10-15 \mathrm{~m} \mathrm{~s}^{-1}(20-30 \mathrm{kt})$ was in place over eastcentral and northeastern Colorado and the Nebraska panhandle. Widespread rainfall developed by late on 17 March over the urban corridor of Colorado. Furthermore, surface pressure over the northern Rockies rose significantly, contributing to enhanced ageostrophic northerly winds over the high plains of Wyoming, into the northern Colorado Front Range (specific surface observations are discussed in the next section). Since pressures did not fall rapidly on the south/east side of the system, this was not classified as a cyclogenesis event.

High relative humidity values were present through most of the troposphere over the central Rockies late on 17 March, extending around the low into the desert southwest. Substantial, organized Gulf of Mexico moisture transport was just beginning to increase rapidly over the southern and central plains in the low- and midlevels (see Fig. 6). Sounding analyses for the plains at this time (not shown) indicated that strong southeasterly flow already was becoming established from the surface to $300 \mathrm{mb}$ over the high plains, bringing Gulf of Mexico moisture northwestward, with relative humidity values above $70 \%$ measured through nearly the entire troposphere. The synoptic signature of the moisture transport became well-established in the midlevels as largescale lifting was occurring over the central and northern high plains (western South Dakota, Nebraska, Kansas, and eastern Wyoming/Colorado).

The 500-mb closed low-pressure system moved slowly to the east-southeast from 0000 UTC 18 March to 0000 UTC 19 March (Fig. 7a). By 0000 UTC 19 March, the deep closed low was centered over the Texas panhandle with the surrounding cyclonic flow extending into Kansas, Colorado, and Wyoming. This cyclonic upslope flow enhanced the strong synopticscale uplift (Fig. 7b). The 700-mb relative humidity analysis in Fig. 7a shows the direct transport of Gulf of Mexico moisture into the Rocky Mountain Front Range, which is consistent with the analysis by Doesken (2003) for this event. For a 36-h period (0000 UTC 18 March through 1200 UTC 19 March), this warm, deep conveyor belt transported large amounts of moisture directly from the southern plains/Gulf of Mexico northwestward into the central Rockies. 


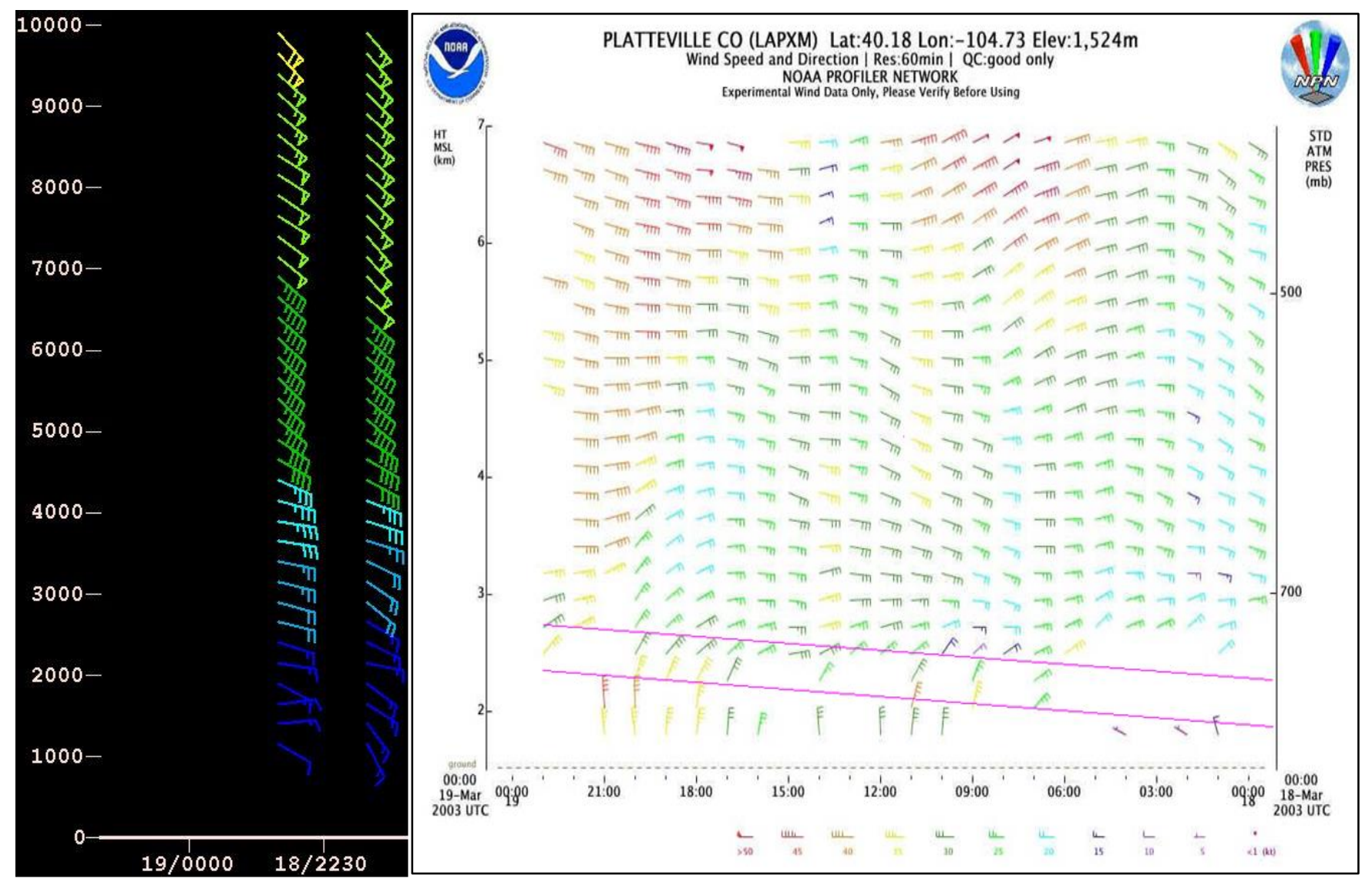

Figure 8. (a, left) Wind profiler data (kt, m AGL) for Haviland, KS, at 2200-2300 UTC 18 March. (b, right) Wind profiler data for Platteville, CO, located approximately $40 \mathrm{~km}$ north of Denver (also see Fig. 3a for this location) for 0000 UTC 18 March-0000 UTC 19 March. Time increases from right to left. The area between the magenta lines represents the shear layer discussed in the text.

A more detailed examination at 0000 UTC 19 March indicated the presence a wide $(\sim 450 \mathrm{~km})$ belt of southerly midlevel $(700 \mathrm{mb})$ flow extending from the Texas/Louisiana region northward into Arkansas, where it began to turn gradually to the west. The belt became oriented east-southeasterly over nearly the entire states of Kansas and Nebraska. For example, the Haviland, Kansas (in south-central Kansas), profiler measured 10-18 $\mathrm{m} \mathrm{s}^{-1}$ (20-35 kt) east-to-southeast winds in the 750-550-mb layer at 2230 UTC 18 March, just before a data outage (Fig. 8a). As this flow began to approach the Rocky Mountain barrier over eastern Wyoming/Colorado, the backing trend continued and the winds were oriented east-northeast (Fig. 8b). The wind speeds through this entire fetch were analyzed by the Eta model at $10-21 \mathrm{~m} \mathrm{~s}^{-1}(20-40$ $\mathrm{kt})$. Temperatures of 0 to $-3^{\circ} \mathrm{C}$ at $700 \mathrm{mb}$ permeated the air mass, with relative humidity values at or above 90\% in the 1000-500-mb layer. The speed, expanse, moisture content, and duration of this conveyor belt were extremely anomalous for Front Range snowstorms (Doesken 2003; Weaver 2003; T. Schlatter 2003, personal communication), and even more impressive than the moisture content and expanse for the storm in Marwitz and Toth (1993).

Conventional $10.7-\mu \mathrm{m}$ infrared satellite imagery at 1800 UTC 18 March (Fig. 9) also showed the large extent of the moisture transport east and north of the parent circulation of the storm, extending from the Gulf Coast northwestward directly into western Kansas and northern Colorado. The wide belt of cold tops extending from Texas/Louisiana northwestward into western Kansas and then eastern Colorado corresponds well to the previously described warm conveyor belt as analyzed by the Eta model and profiler data. At the surface, this conveyor belt was producing widespread precipitation, including convection, late on March 18 (Figs. 10a and 11), and at this time dew points were observed in excess of $4.4^{\circ} \mathrm{C}\left(40^{\circ} \mathrm{F}\right)$ over eastern Colorado and in excess of $10^{\circ} \mathrm{C}\left(50^{\circ} \mathrm{F}\right)$ over central Kansas and southern Nebraska - and even higher to the south and east. 


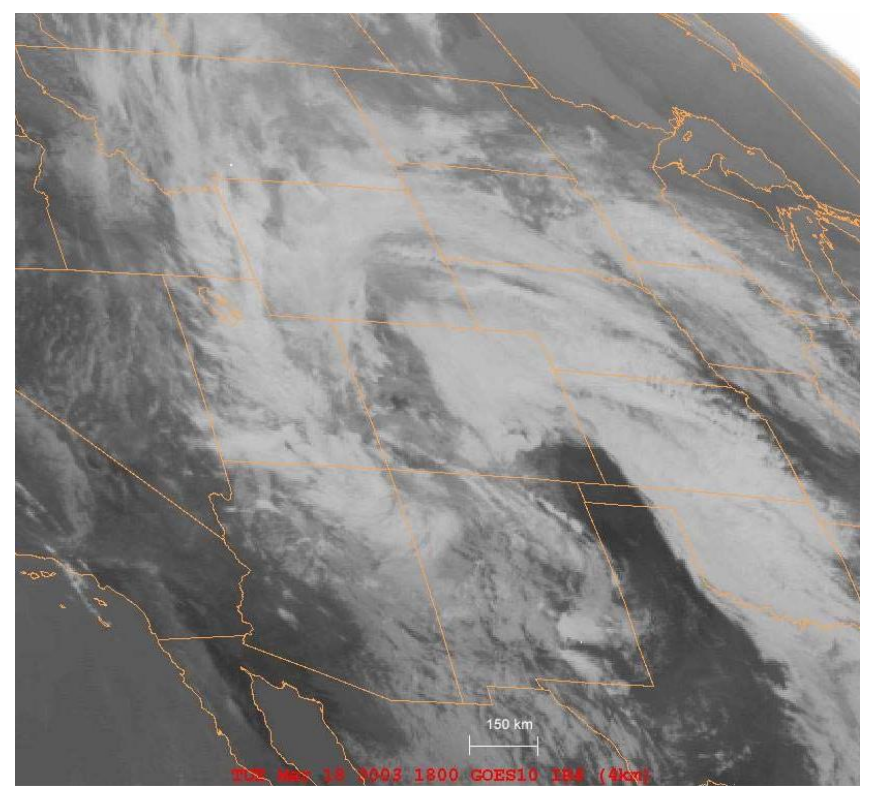

Figure 9. NOAA's GOES-west conventional infrared image at 1800 UTC 18 March 2003, centered on Colorado.

Simultaneously, the precipitation rates over the eastern foothills and urban corridor had increased to moderate and at times heavy (Fig. 3b); this will be discussed later as local radar observations are presented. Meanwhile, an 800-mb analysis (Fig. 10b) captured the strength of the organized conveyor belt, northerly flow developing on the Front Range, and colder temperatures over eastern Wyoming.

The scenario described at about 0000 UTC 19 March was quasi-stationary for the next 9 hours or so. Later on 19 March, the pronounced warm conveyor belt began to weaken significantly (not shown). At 1700 UTC 19 March, the storm was rapidly decreasing in intensity over the Front Range of Colorado as the easterly component of wind aloft and the associated moisture supply and uplift weakened. The trajectory of inflow no longer originated from the Gulf of Mexico region, and the advection of high-reflectivity cells into eastern Colorado had ended. By this time, northern Colorado was experiencing northeast-to-north flow from the surface up through the midlevels of the atmosphere. This backing of winds with time was the result of synoptic forcing as the large low-pressure system moved eastward. As a result, light-to-moderate precipitation was confined to the eastern foothills and the immediately adjacent plains by midday on 19 March. By 2100 UTC 19 March, all but the extreme southern portion of the urban corridor, where the northerly flow is a local upslope component due to the presence of the Palmer Divide south of Denver, was free of precipitation.
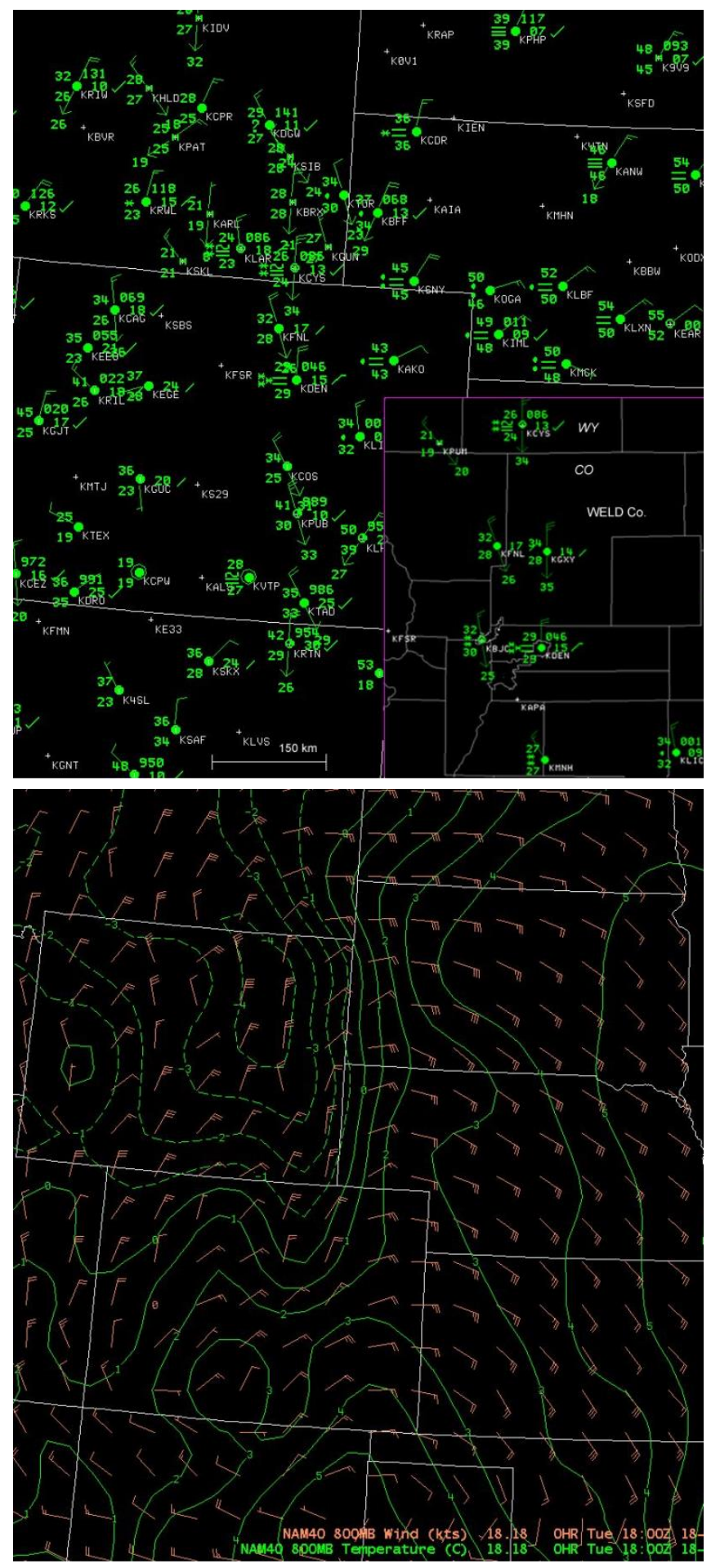

Figure 10. (a, top) Surface METAR observations for 0000 UTC 19 March. (b, bottom) Eta-model analyzed 800-mb winds (kt) and temperature $\left({ }^{\circ} \mathrm{C}\right)$ at 1800 UTC 18 March. The inset portion on the lower right portion of (a), bounded by the magenta-colored box, is a zoomed-in portion of the main geographical area with observations at the same time, centered on southern Weld County in northeastern CO (refer to Fig. 3a for county names). Observed winds and temperatures are shown in $\mathrm{kt}$ and ${ }^{\circ} \mathrm{F}$, respectively. 


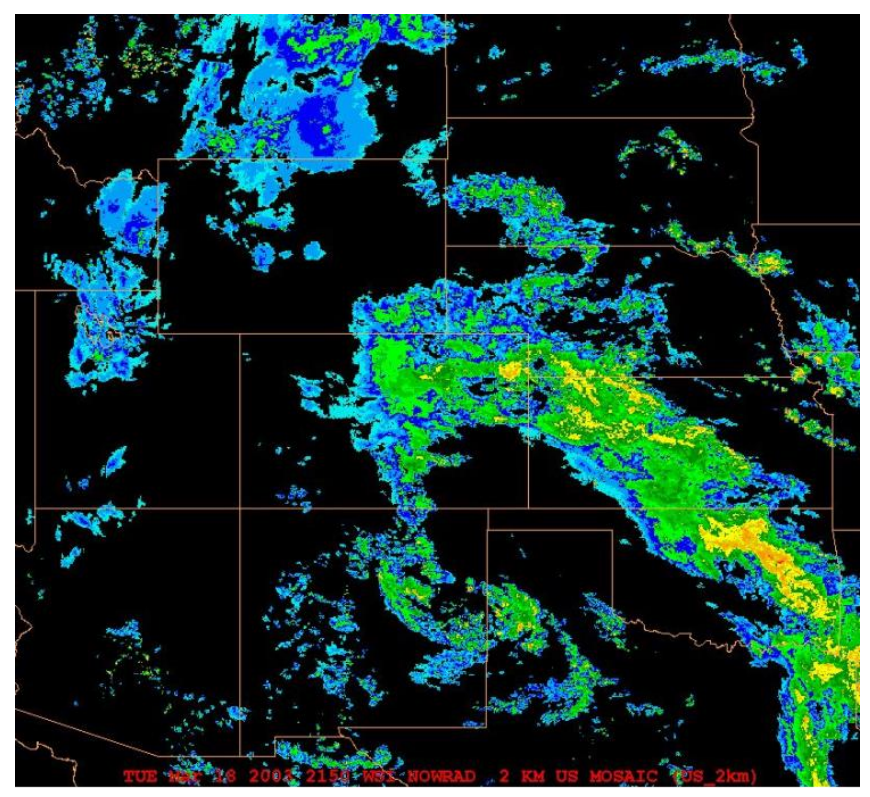

Figure 11. NEXRAD mosaic of 0.5-degree reflectivity (dBZ) at 2150 UTC 18 March 2003, from NOAA/NWS.

\section{Cold-air damming}

Table 1 summarizes important mesoscale processes during the 17-19 March 2003 time period for the Front Range. These processes include the role of low-level stability, blocking, southward acceleration of winds along the foothills, precipitation rates, cold and warm advection in the low levels, and the evolution of cold-air damming.

Overall, the mesoscale features of this intense storm, and in particular the embedded region of northerly flow that resembled a barrier jet, were critically important to the resulting precipitation distribution and thus to the impact on the populace. Observationally, the presence of the blocking and surge-induced cold-air dome (Schwerdtfeger 1975; Richwien 1980; Dunn, 1987; Colle and Mass 1995), along with diabatic cooling, produced temperatures favoring primarily snow instead of rain in the urban corridor, and secondly provided uplift strong enough

Table 1. Timeline of the important mesoscale processes. The forcing processes are (1) low-level blocking first apparent along the urban corridor/eastern foothills of northern $\mathrm{CO},(2)$ onset of low-level cold advection from the north in the surface observations and in the Eta 800-mb analyses for the urban corridor, (3) establishment of marked acceleration of low-level flow towards the south along the urban corridor, (4) stable conditions in the low levels over the eastern plains of $\mathrm{CO}$, as analyzed by the Eta model, (5) end of cold advection signature in the surface observations along the urban corridor, (6) strong melting level signature in the CHILL radar data, (7), upstream low-level convective instability in place in the Eta analyses/6-h forecasts, (8) deep surface-based isothermal layer inferred from observations along Front Range, (9) peak of the low-level convectively unstable conditions over the eastern CO plains in the Eta analyses, (10) end of the cold advection signature at $800 \mathrm{mb}$ over the urban corridor in the Eta analyses, (11) rapid increase/peak of cold-airdamming signature over the urban corridor, and (12) heavy precipitation rates measured at two urban corridor sites.

\begin{tabular}{|c|c|c|c|c|c|c|c|c|}
\hline $\begin{array}{l}\text { Forcing } \\
\text { Process }\end{array}$ & $\begin{array}{l}\text { 12-18 UTC } \\
17 \text { March }\end{array}$ & $\begin{array}{c}18 \text { UTC 17 } \\
\text { March-00 } \\
\text { UTC } 18 \text { March }\end{array}$ & $\begin{array}{c}\text { 00-06 UTC } \\
18 \text { March }\end{array}$ & $\begin{array}{l}\text { 06-12 UTC } \\
18 \text { March }\end{array}$ & $\begin{array}{l}\text { 12-18 UTC } \\
18 \text { March }\end{array}$ & $\begin{array}{c}\text { 18 UTC 18 } \\
\text { March-00 } \\
\text { UTC 19 March }\end{array}$ & $\begin{array}{l}\text { 00-06 UTC } \\
19 \text { March }\end{array}$ & $\begin{array}{c}\text { 06-12 UTC } \\
19 \text { March }\end{array}$ \\
\hline 1 & $\mathbf{X}$ & & & & & & & \\
\hline 2 & & $\mathbf{X}$ & & & & & & \\
\hline 3 & & $\mathbf{X}$ & $\mathbf{X}$ & & & & & \\
\hline 4 & & $\mathbf{X}$ & $\mathbf{X}$ & & & & & \\
\hline 5 & & & $\mathbf{X}$ & & & & & \\
\hline 6 & & & $\mathbf{X}$ & $\mathbf{X}$ & $\mathbf{X}$ & & & \\
\hline 7 & & & & $\mathbf{X}$ & $\mathbf{X}$ & & & \\
\hline 8 & & & & & & $\mathbf{X}$ & $\mathbf{X}$ & \\
\hline 9 & & & & & & $\mathbf{X}$ & $\mathbf{X}$ & \\
\hline 10 & & & & & & & $\mathbf{X}$ & $\mathbf{X}$ \\
\hline 11 & & & & $\mathbf{X}$ & $\mathbf{X}$ & $\mathbf{X}$ & $\mathbf{X}$ & \\
\hline 12 & & $\mathbf{X}$ & $\mathbf{X}$ & $\mathbf{X}$ & $\mathbf{X}$ & $\mathbf{X}$ & $\mathbf{X}$ & \\
\hline
\end{tabular}

to produce snowfall rates of $2.5-7.5 \mathrm{~cm} \mathrm{~h}^{-1}$ for more than 36 hours locally. This dammed cold layer was characterized by markedly enhanced northerly flow. The upslope flow forced by large-scale conditions began on 17 March and lasted into 19 March. Early in this period, northerly flow developed along the eastern slope of the barrier via blocking of the upslope flow with a geostrophic adjustment consistent with traditional barrier jet theory (Parish 1982; Pierrehumbert and Wyman 1985; Cox et al. 2005;
Loescher et al. 2006). Enhancement of that northerly flow occurred via surges forced by larger-scale conditions east of the barrier, as discussed in section 2 . The enhanced northerly flow in the present case occurred on the cold side of a persistent rain/snow boundary and thus was supported in part by diabatically forced mesoscale convergence, a feature documented in previous heavy springtime snowfalls in the urban corridor (Marwitz and Toth 1993), which will be discussed in more detail later in this section. 
Surface observations at 1800 UTC 17 March are shown in Fig. 12a, at a time when blocking of easterly winds (over eastern Colorado and southeastern Wyoming) was already in place and northerly flow was developing along the Colorado Front Range. Meanwhile, a surge of colder northerly flow was evident over eastern Wyoming, with a nose of stronger winds oriented at $360^{\circ}$. Postfrontal cold advection within the northerly flow characterized the surface observations from about 1800 UTC 17 March to 0500 UTC 18 March [unlike the Marwitz and Toth (1993) event, where little to no cold advection was measured] as well as the $800-\mathrm{mb}$ model-analyzed fields through about 0600 UTC 19 March (a representative 800-mb analysis was shown in Fig. 10b). Representative calculations of temperature advection ranged from -0.7 to $-2.5^{\circ} \mathrm{C} \mathrm{h}^{-1}$ at the surface and $800 \mathrm{mb}$ between 1800 UTC 17 March and 0000 UTC 19 March. The cold advection complicated the situation and clearly did not indicate that the northerly flow regime was a classic barrier jet, as in the Parish (1982) study.

The surface-based cold-air dome, which developed late on 17 March, and the enhanced northerly flow were in place by 0000 UTC 18 March. This structure was dominant in the METAR observations shown in Fig.10a at 0000 UTC 19 March (note the urban corridor and foothill observations of enhanced flow parallel to the north-south barrier). Most surface observations along the urban corridor at that time indicated sustained northerly winds around 5-10 $\mathrm{m} \mathrm{s}^{-1}$ (10-20 kt). Generally, northerly winds of $5-13 \mathrm{~m} \mathrm{~s}^{-1}$ (10-25 kt) occurred during the period of extremely heavy snowfall from 0000 UTC 18 March through 1200 UTC 19 March, with locally stronger gusts. As the storm progressed, the eastward extent of the northerly winds increased slowly. Also notable was that local wind-prone areas just east of the foothills experienced surface northerly wind gusts in the 13-21 $\mathrm{m} \mathrm{s}^{-1}(25-40 \mathrm{kt})$ range associated with this blocked structure, causing extensive blowing and drifting snow. Meanwhile, well out on the plains, eastnortheasterly flow at $5-10 \mathrm{~m} \mathrm{~s}^{-1}(10-20 \mathrm{kt})$ was common through the period [see the Akron (AKO) wind observation in Fig. 10a].

The evolution of the wind profile at Platteville, Colorado (PTL, a location about $35 \mathrm{~km}$ east of the foothills, see Fig. 3a), captured the low-level northerly flow well and indicated deepening surface-based northerlies with time, as well as strong overrunning easterly flow. Figure $8 \mathrm{~b}$ shows the evolution of this layer from 0000 UTC 18 March through 0000 UTC 19
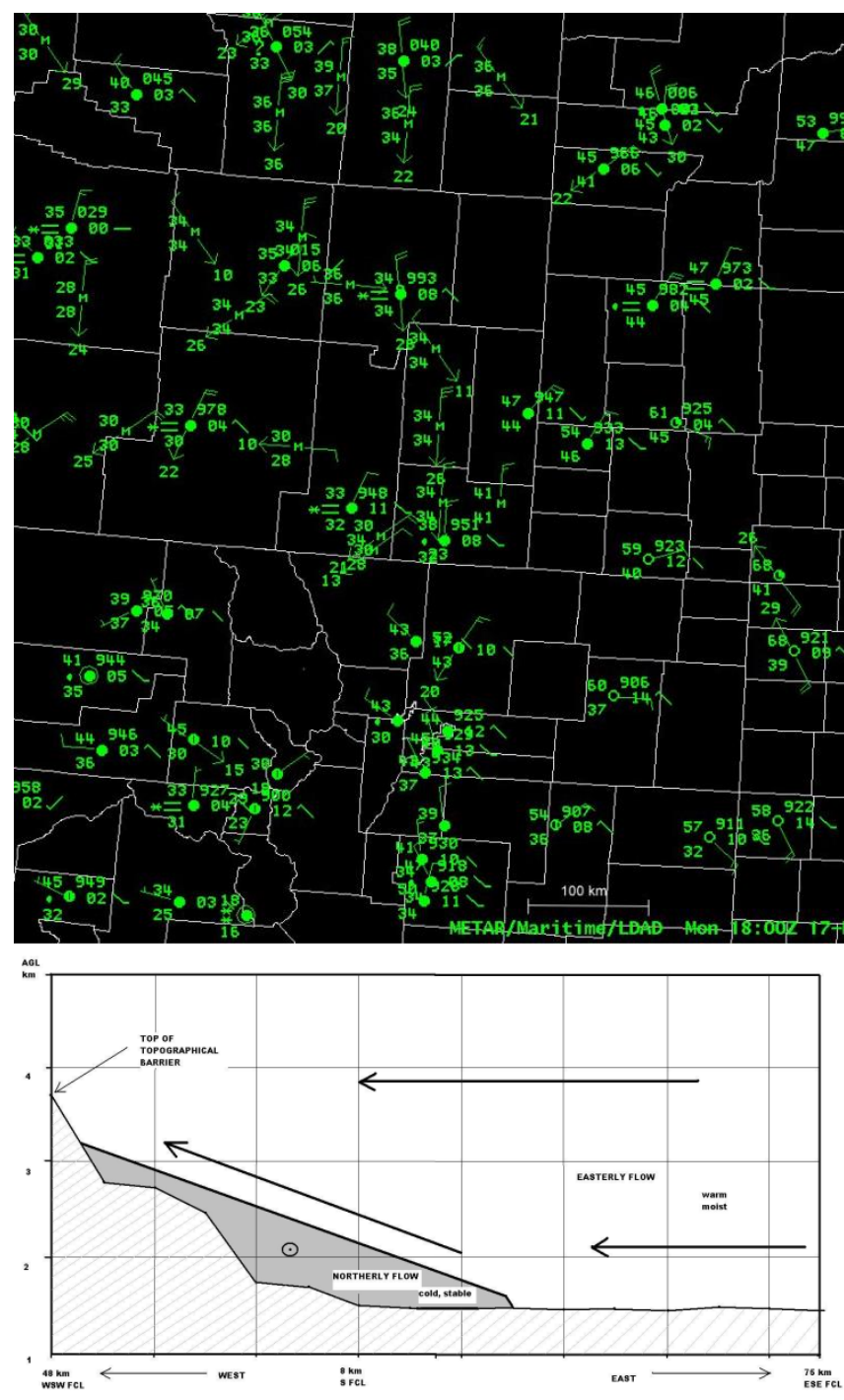

Figure 12. (a, top) Surface METAR observations for 1800 UTC 17 March 2003. (b, bottom) Schematic of the cold-air-damming structure present from about 0600 UTC 18 March to 0600 UTC 19 March along Colorado's northern Front Range, based on observations and NCEP model analyses. This is a vertical crosssection, oriented west-to-east (latitude $40.5^{\circ} \mathrm{N}$ ), with the shaded area representing the blocked layer. Other important components are the high moisture content upstream, northerly flow within the blocked layer, and uplift generated by the blocked layer. Crosshatched region is the terrain.

March. Generally, easterly flow at $13-26 \mathrm{~m} \mathrm{~s}^{-1}(25-50$ kt) was present in the deep layer from 700-400 mb, starting around 0600 UTC 18 March. Below $700 \mathrm{mb}$ the wind profile exhibited significant directional shear, with a layer of northerly flow near the surface to about $750 \mathrm{mb}$. The magnitude of this northerly flow was $13-21 \mathrm{~m} \mathrm{~s}^{-1}(25-40 \mathrm{kt})$ after 0600 UTC. This represented the blocked layer. Note that an elevated wind maximum is not readily obvious in the PTL wind 
profiles or the CSU CHILL ${ }^{2}$ radar measurements (to be discussed below), perhaps due in part to missing data in the case of the profiler. The lack of an elevated wind maximum was consistent with the previous findings that this was not a classic barrier jet signature.

The depth of the northerly flow was about $1.1 \mathrm{~km}$ and the maximum strength was about $21 \mathrm{~m} \mathrm{~s}^{-1}$ (40 kt) at PTL during the afternoon of 18 March. Northerly flow veered towards northeasterly with height such that at about $2.5 \mathrm{~km}$ mean sea level (MSL) the wind direction was directly northeast. Just to the east at 2324 UTC 18 March, the radar-derived vertical wind profile at the CHILL radar site is shown in Table 2. These measurements showed a maximum strength of about $26 \mathrm{~m} \mathrm{~s}^{-1}(50 \mathrm{kt}$ ) around $1.7 \mathrm{~km} \mathrm{MSL}$ (only about $300 \mathrm{~m}$ above the ground), with the flow becoming oriented at $45^{\circ}$ at just over $2 \mathrm{~km} \mathrm{MSL}$, providing corroboration of the slope of the top of the cold dome. The maximum speed was only slightly stronger than the wind at the lowest level (1477 m MSL). Although we do not have direct observations of vertical motion, these wind data, along with numerical simulations (both the Eta analyses and MM5 simulations to be discussed later), confirmed that easterly flow approaching the Front Range, rather than being simply lifted by the barrier itself, was instead initially lifted well east of the barrier by the dammed cold dome. This is illustrated in the schematic in Fig. 12b.

Table 2. Vertical profile of winds as measured by the CHILL radar (see the CHILL location in Fig. 3a) at 2324 UTC 18 March. The measurements were taken at a horizontal distance of $5 \mathrm{~km}$ from the radar site for each applicable elevation angle.

\begin{tabular}{|c|c|c|c|}
\hline Elev. Angle $\left(^{\circ}\right)$ & MSL (m) & Wind Dir. $\left({ }^{\circ}\right)$ & $\begin{array}{c}\text { Wind Speed } \\
\left(\mathbf{m ~ s}^{-1}\right)\end{array}$ \\
\hline 0.6 & 1477 & 349.3 & 21.2 \\
\hline 1.5 & 1560 & 000.5 & 20.8 \\
\hline 2.4 & 1637 & 004.7 & 23.7 \\
\hline 3.3 & 1723 & 009.7 & 25.8 \\
\hline 4.3 & 1803 & 017.7 & 24.9 \\
\hline 5.2 & 1885 & 027.8 & 23.6 \\
\hline 6.1 & 1970 & 036.6 & 22.4 \\
\hline 7.0 & 2050 & 043.5 & 21.1 \\
\hline 8.1 & 2142 & 048.4 & 19.7 \\
\hline
\end{tabular}

The top of the relatively stable core of cold air, and the layer of northerly winds embedded within it, were sloped upwards to the west, essentially modifying the terrain encountered by upslope flow

\footnotetext{
2 The CHILL radar derives its name from the fact that it was first located in CHicago, ILL. See Brunkow et al. (2000) and Kennedy and Rutledge (2011) for a description of the CHILL radar (www.chill.colostate.edu).
}

(Fig. 12b). This is not the same lifting mechanism as that described in Dunn (1992), where the Palmer Divide-induced uplift of the barrier jet in the southern portion of the urban corridor was studied. Figure 13 shows the thermal and wind structure at 0000 UTC 19 March in the Eta 6-h forecast vertical cross-section at $40.5^{\circ}$ latitude; this is a representative cross-section of thermodynamic and dynamic fields for the duration of heavy snowfall over the Front Range for the storm. The oval-shaped annotation shows the location of the cold dome which developed over the region immediately adjacent to the foothills (corresponding to the shaded region in Fig. 12b). The dome is capped by a strong inversion, and relatively warmer air is in place above and east of this dome. Also note the northerly winds just east of the Front Range with wind speeds of $10-21 \mathrm{~m} \mathrm{~s}^{-1}(25-40 \mathrm{kt})$. The northerly flow was about $1 \mathrm{~km}$ deep just east of the barrier, but less than half that $30 \mathrm{~km}$ east of the barrier (based primarily on radar and profiler measurements). This depth was notably greater than that of the Marwitz and Toth (1993) storm. The layer of northerly flow exhibited strong stability and strong vertical wind shear at the top of the stable layer (also refer to Fig. 8). Medina et al. (2005) also documented a laterally sloped shear zone in their studies of orographic events in the European Alps and Oregon's Cascade Mountains. Essentially, they found a signature of blocked or retarded low-level flow, as in the present case, and then less blocked and more crossbarrier flow as one proceeded vertically. A layer of strong vertical wind shear also separated these two regimes. The study found that orographic processes alone were responsible for this structure. Furthermore, their numerical investigation indicated that with a reduced Froude number (Fr), complete blocking of the low-level flow occurred and the shear zone was even stronger. Another example is from the Cox et al. (2005) case characterized by less-stable low-level conditions. They documented the lateral slope upwards (towards the east) of a low-level jet parallel to the barrier in a storm in the Wasatch Range of Utah. Upstream precipitation enhancement occurred at the convergence zone on the upstream (westernmost) portion of the barrier-parallel or southerly flow zone.

Our findings indicate confirmation of the Medina et al. (2005) scenario for the 2003 storm in the Rocky Mountain Front Range. The height of the Rocky Mountain barrier was likely sufficient to cause complete blocking. However, this cannot be proven conclusively without upstream soundings. The only appropriate NWS radiosonde launch site was the 


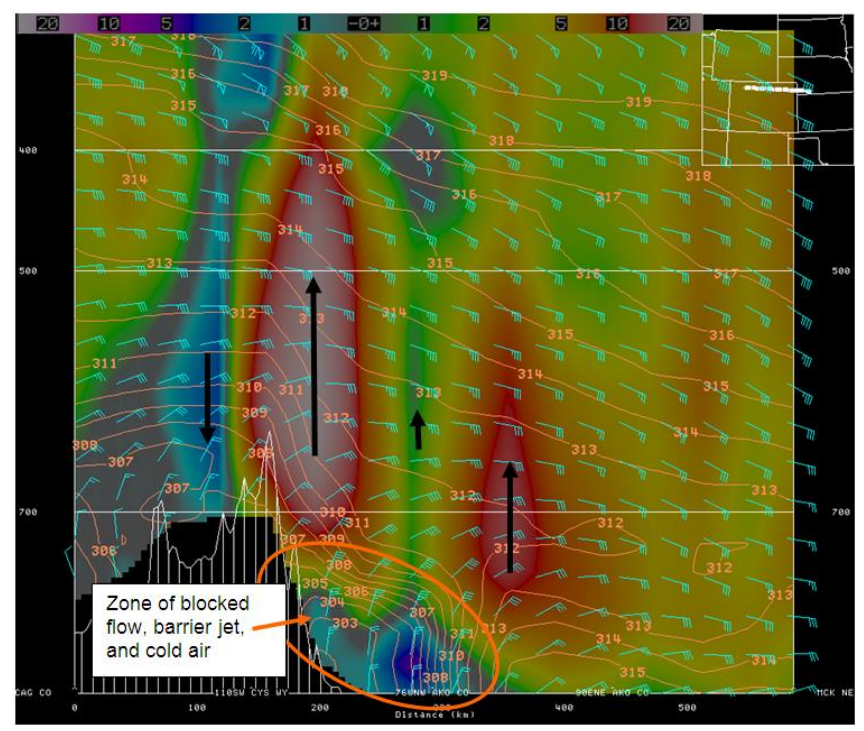

Figure 13. Vertical cross-section oriented approximately E-W and spanning about $575 \mathrm{~km}(350 \mathrm{mi})$, showing equivalent potential temperature $\Theta_{\mathrm{e}}(\mathrm{K})$, winds $(\mathrm{kt})$, and omega $\left(\mu \mathrm{b} \mathrm{s}^{-1}\right)$. This is a 6-h forecast from the Eta model initialized at 1800 UTC 18 March. The vertical axis represents pressure $(\mathrm{mb})$. The cross section extends from Craig, CO, to McCook, NE (see inset on upper right portion). Red regions correspond to omega values of -10 to $-15 \mu \mathrm{b}$ $\mathrm{s}^{-1}$. Vertical arrows depict regions of upward and downward motion. Wind barbs (in light blue) are plotted to depict wind direction only on a planar surface (e.g., a barb pointing straight down on the figure indicates a wind from the north).

Denver location. This was not far enough upstream during the storm for a good approximation of the blocking effect, and during the height of the storm these soundings were not available. An approximation can be obtained from operational numerical solutions. Using the Eta model simulations (12-km horizontal grid spacing), we made an approximation of the Froude number using the upstream air mass in the vicinity of AKO (see Figs. 4 and 10 for this location). The 6-h forecast valid for 1200 UTC 18 March (after the barrier jet-like feature had already been established) indicated widespread upstream convective instability. However at 0000 UTC 18 March, when the low-level northerly flow was increasing, upstream low-level conditions were stable. Both the moist Froude number ( $\left.\mathrm{Fr}^{*}\right)$ and conventional (dry) Fr were calculated for this region:

$$
\begin{aligned}
& F r=\frac{U}{N h}, \text { where } N=\left[\left(\frac{g}{\bar{\Theta}}\right)\left(\frac{d \Theta}{d z}\right)\right]^{1 / 2} \\
& F r^{*}=\frac{U}{N^{*} h}, \text { where } N^{*}=\left[\left(\frac{g}{\bar{\Theta}_{e}}\right)\left(\frac{d \Theta_{e}}{d z}\right)\right]^{1 / 2}
\end{aligned}
$$

where $U$ is the mean wind over the layer, $h$ is the depth of the layer, $N$ is the Brunt-Väisällä frequency, $g$ is gravity, $\Theta$ is potential temperature, $\Theta_{\mathrm{e}}$ is equivalent potential temperature, and $z$ is height.

For this case, we utilized a 1.8-km effective barrier height and an easterly velocity of $10 \mathrm{~m} \mathrm{~s}^{-1}$, consistent with surface observations and model predictions. These numbers yielded the following for an east-west cross-section: $\mathrm{Fr}=0.56$ and $\mathrm{Fr}^{*}=0.71$.

According to the radar observations at this time, most of the northeastern Colorado plains were relatively dry; the Eta analyzed $60-70 \%$ relative humidity in the surface-700-mb layer, and AKO's surface observation indicated a temperature of $14.6^{\circ} \mathrm{C}$ $\left(58.2^{\circ} \mathrm{F}\right)$ and a dew point of $0.6^{\circ} \mathrm{C}\left(33.1^{\circ} \mathrm{F}\right)$, with eastsoutheasterly winds at $8 \mathrm{~m} \mathrm{~s}^{-1}$ gusting to $12 \mathrm{~m} \mathrm{~s}^{-1}$. Since the inflow was not directly easterly, but more east-southeasterly, we recalculated the numbers for a cross section oriented at $120^{\circ}$, yielding: $\mathrm{Fr}=0.59$ and $\mathrm{Fr}^{*}=0.77$.

Past studies have indicated that strong blocking occurs when Fr is approximately 0.7 or less, and significant deceleration occurs when Fr is less than approximately 1.3 (Pierrehumbert and Wyman 1985). Similar results have been obtained for blocked situations upstream of the 2-km barrier along the Alaskan coast (e.g., Loescher et al. 2006).

Thus, the observations for 0000 UTC 18 March indicated that the easterly inflow over the northeastern Colorado plains would experience significant deceleration and blocking. This effect, if prolonged over several hours as in the current case, would likely lead to low-level northerly flow prior to the onset of convectively unstable conditions on the eastern plains.

Near the peak of the storm at 0000 UTC 19 March, the low-level northerly flow was capped by a strong stable layer, as shown in Fig. 13. Note the contours of $\Theta_{\mathrm{e}}$ sloping upwards to the west over the foothills and adjacent plains. We estimated quasivertical profiles from surface observations at different elevations to look in more detail at the lapse rates in the surface-based cold dome. Figure 14 shows that during the height of the storm, just below freezing conditions existed at the National Wind Technology Center (NWTC) - just south of Boulder at an elevation of $1824 \mathrm{~m}(6092 \mathrm{ft})$. Using the mean temperature of $-1^{\circ} \mathrm{C}$ during the heavy snowfall, and unofficial observations of $-2^{\circ} \mathrm{C}$ at $2515 \mathrm{~m}(8400 \mathrm{ft})$ in the foothills west of Boulder (T. Spangler 2003, personal communication), we found an approximate mean lapse 

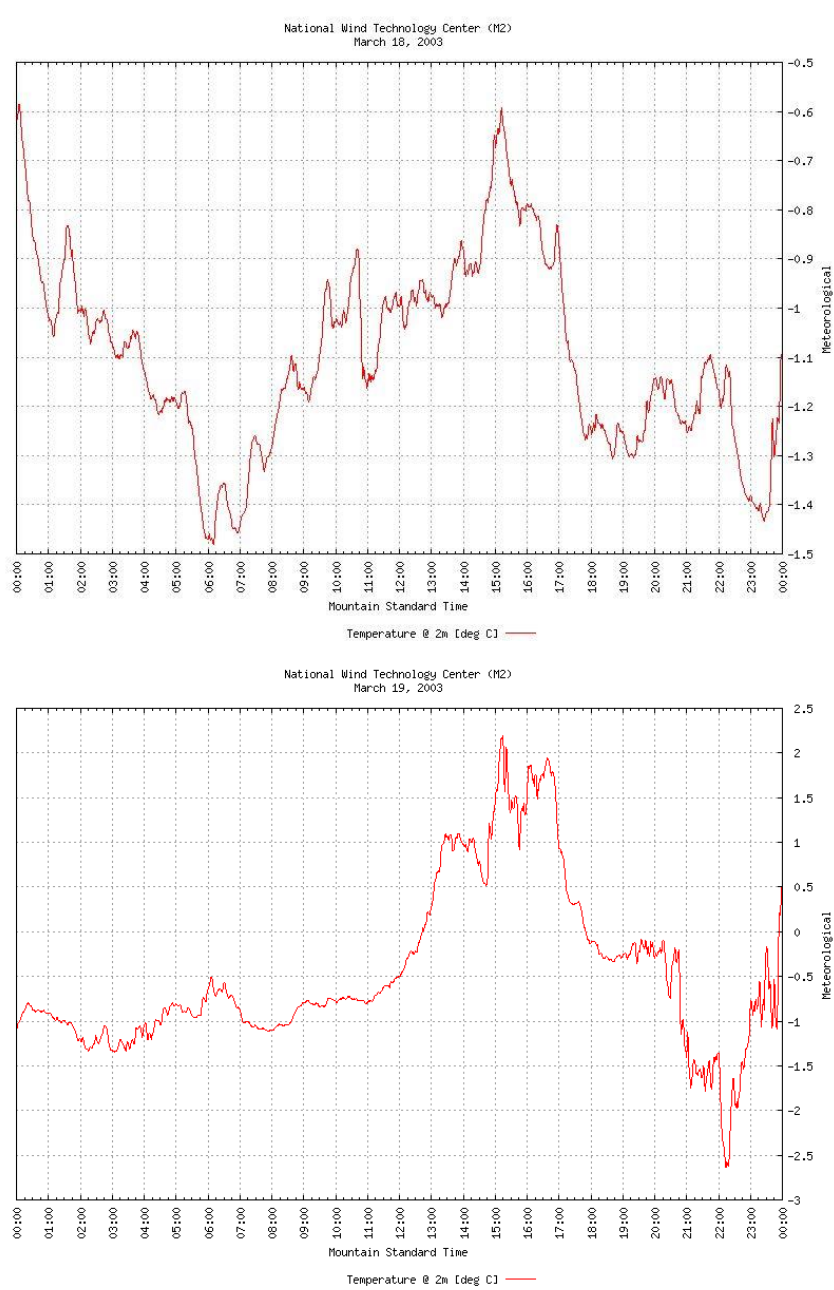

Figure 14. (a, top) Temperature $\left({ }^{\circ} \mathrm{C}\right)$ trace for the 2-m-high sensor at NWTC for 18 March, and (b, bottom) 19 March 2003. For the location of the NWTC site in Jefferson County, see Fig. 3. A temperature of $1{ }^{\circ} \mathrm{C}$ corresponds to $1.8^{\circ} \mathrm{F}$ and each $1^{\circ} \mathrm{C}$-interval represents $1.8^{\circ} \mathrm{F}$.

rate of only $1.4{ }^{\circ} \mathrm{C} \mathrm{km}^{-1}$, which is very stable. Above this layer, near-neutral stability was predicted in a deep layer (Fig. 13). To the east of the cold dome, deep convective instability was present in the low- and midlevels.

Figure 13 also shows deep, cold-air damminginduced uplift, over and just east of the foothills, extending from about 750 to $400 \mathrm{mb}$. Negative values of omega predicted in this 6 -h forecast were in the $15-25 \mu \mathrm{b} \mathrm{s}^{-1}$ range for the primary uplift areas at the meso-frontal boundary to the east of the mountains and approaching the steepest terrain gradients (longer arrows directed upwards). A region of weak upward motion was between these two strong uplift regions, and downward vertical motion existed in the lee of the peak as expected from canonical moist mountain wave dynamics. Now, clearly there were other lifting mechanisms, such as large-scale forcing (see section 2), which was significant at this time. However, examination of all of the Eta analyses and 3-6-h forecasts during the time period 0000 UTC 18 March through 1800 UTC 19 March revealed persistently strong upward motion (omega of -15 to $-25 \mu \mathrm{b} \mathrm{s} \mathrm{s}^{-1}$ ) directly over the foothills, and extending east of the foothills $50 \mathrm{~km}$ or so in the $700-500-\mathrm{mb}$ layer. To the east, the uplift regions were substantial, but more transient. These more transient regions likely owed their existence to larger-scale forcing. Also, note that the primary zones of uplift were located just above the packed contours of $\Theta_{e}$, rather than in close proximity to the sloped terrain, until very high elevations were reached near the Continental Divide. This confirms that the uplift was primarily due to damming in the region of interest rather than direct lifting by terrain (Fig. 12b). Interestingly, a rough geometric calculation utilizing the measurements of the slope $\left(\sim 1.5^{\circ}\right)$ and the observed easterly wind component (Fig. 8b) at the top of the cold dome yields an approximate uplift of -25 $\mu \mathrm{b} \mathrm{s}^{-1}$.

The region of transition from rain to snow was generally oriented north-south and located between AKO (located $160 \mathrm{~km}$ east-southeast of Fort Collins) and the I-25 corridor at 0000 UTC 19 March (see Fig. 10a). This demarcation developed about 18-24 h earlier (see Fig. 3b) and did not move significantly as warm advection on the east side of the transition was occurring simultaneously with low-level cold advection on the west side (Fig. 10 and Table 1) through about 0600 UTC 19 March. Importantly, strong diabatic cooling was occurring over and east of the transition zone (as in the storm described by Heffernan and Marwitz 1996). To illustrate this point, consider that in AKO, approximately $160-170 \mathrm{~km}$ east of the urban corridor, the temperature was $+6^{\circ} \mathrm{C}(42.8$ ${ }^{\circ} \mathrm{F}$ ) with east-northeasterly winds. The rain/snow demarcation (at approximately $0^{\circ} \mathrm{C}$ or $32^{\circ} \mathrm{F}$ ) was along a $330^{\circ}$-oriented line from just east of Denver International Airport to just west of Greeley. At first guess, considering the elevation of AKO relative to that of the rain/snow line and using a moist adiabatic lapse rate, the surface temperature should have only dropped about $1.5^{\circ} \mathrm{C}\left(2.7^{\circ} \mathrm{F}\right)$ if direct terrain lifting was dominant from AKO to the transition zone. The damming scenario includes cold wedge-induced uplift beginning at the eastern edge of the wedge, in the vicinity of the rain/snow line and the eastern edge of the enhanced northerly winds (Fig. 12b). Diabatic 
cooling and cold advection (calculated previously at about $0.8^{\circ} \mathrm{C} \mathrm{h}^{-1}$ for $800 \mathrm{mb}$ ) apparently accounted for the additional cooling of $\sim 4.5^{\circ} \mathrm{C}\left(8.1^{\circ} \mathrm{F}\right)$ for surface air parcels at the rain/snow interface. The presence of substantial reflectivity in this region supported the implication of large values of diabatic cooling at this time. Another simple approximation illustrates this point well: employing the 12-h Eta forecast sounding for $\mathrm{AKO}$ at $0000 \mathrm{UTC} 19$ March (not shown), the depth of the column of temperature greater than $0^{\circ} \mathrm{C}$ was about $1 \mathrm{~km}$, or up to $750 \mathrm{mb}$. Using the representative approximation of the snowfall rate into this column to be $5-10 \mathrm{~mm} \mathrm{~h}^{-1}$ (estimated from the total precipitation observed over the eastern plains and the radar observations late on 18 March), melting all of that snowfall-during the $2.2 \mathrm{~h}$ required for the column to move westward at $10 \mathrm{~m} \mathrm{~s}^{-1}(20 \mathrm{kt})$ to the eastern edge of the cold pool-would cool that column approximately $3.2-6.3^{\circ} \mathrm{C}$. The surface temperature at $0000 \mathrm{UTC}$ at $\mathrm{AKO}$ was $6^{\circ} \mathrm{C}\left(42.8^{\circ} \mathrm{F}\right)$, and the modelpredicted mean column temperature was about $5^{\circ} \mathrm{C}$. Thus, at first guess, diabatic cooling appeared to account for most of the cooling over and east of the rain/snow demarcation, as in the Marwitz and Toth (1993) study. Another potential effect of this cooling was small-scale upward motion in the vicinity of significant melting, via mesoscale frontogenesis or melting-induced circulations (Szeto et al. 1988).

Much warmer surface conditions and rain were observed just east of the cold-air damming region for much of the 0600 UTC 18 March to 0600 UTC 19 March period, where diabatic cooling was insufficient to overcome warm advection from the east. Evaporation was examined as a potential contributor to cooling in the northerly flow regime, but the source region for the northerly winds exhibited small dew point depressions (up to only a few ${ }^{\circ} \mathrm{C}$ ) even during the initial stages of blocking by the terrain (the early hours of 17 March).

Further documentation of the development and vertical structure of the cold wedge was provided by Doppler radar data collected over northeastern Colorado by the CHILL and Pawnee radars (Fig. 3a). Figure 15a shows a distinct signature of the melting level (Herzegh and Jameson 1992) early in the storm (0600 UTC $18 \mathrm{March}$ ) in a $286^{\circ}$-azimuth range-height indicator (RHI) plot of conventional reflectivity from the CHILL radar. This azimuth was chosen so that sampling of the layer of northerly flow itself would be possible (i.e., a wind component towards the radar would be measured; the CHILL location itself is well
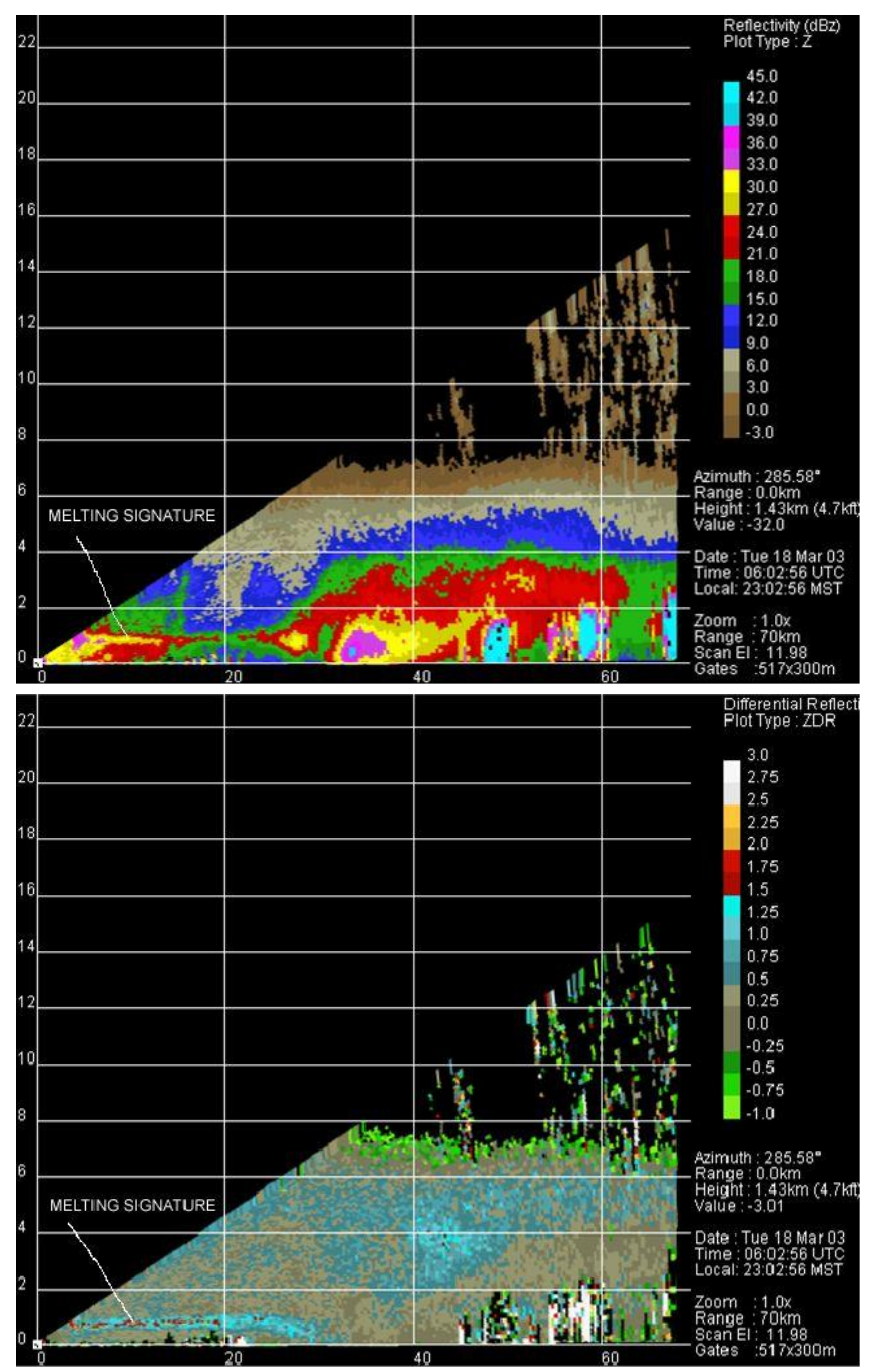

Figure 15. (a, top) RHI of CHILL reflectivity at 0603 UTC 18 March. (b, bottom) RHI of CHILL differential reflectivity at 0603 UTC 18 March. These RHIs are oriented at the $286^{\circ}$ azimuth [radar location is at lower-left $(0,0)$ on the horizontal and vertical axes]. Scales are marked in $\mathrm{km}$ both horizontally and vertically. The location of the snow/rain boundary is at $\sim 30 \mathrm{~km}$ from the radar at this time. Reflectivity $>40 \mathrm{dBZ}$ in (a) represents terrain features.

east of the foothills). The melting level, noted as the horizontal quasi-linear feature of enhanced reflectivity at $\sim 1 \mathrm{~km}$ above ground level (AGL), extended 5-25 $\mathrm{km}$ from the radar. Between $25-30 \mathrm{~km}$, the melting level descended as diabatic cooling and cold advection were taking over. Beyond $\sim 30 \mathrm{~km}$, snow was reaching the ground. Medina et al. (2005) also documented the descent of the bright band towards the ground as one approaches a barrier in studies of orographic events with stable upstream lapse rates in the European Alps and Oregon's Cascade Mountains.

The differential reflectivity (Fig. 15b) signature of melting at this time is even more distinct [see Kennedy 


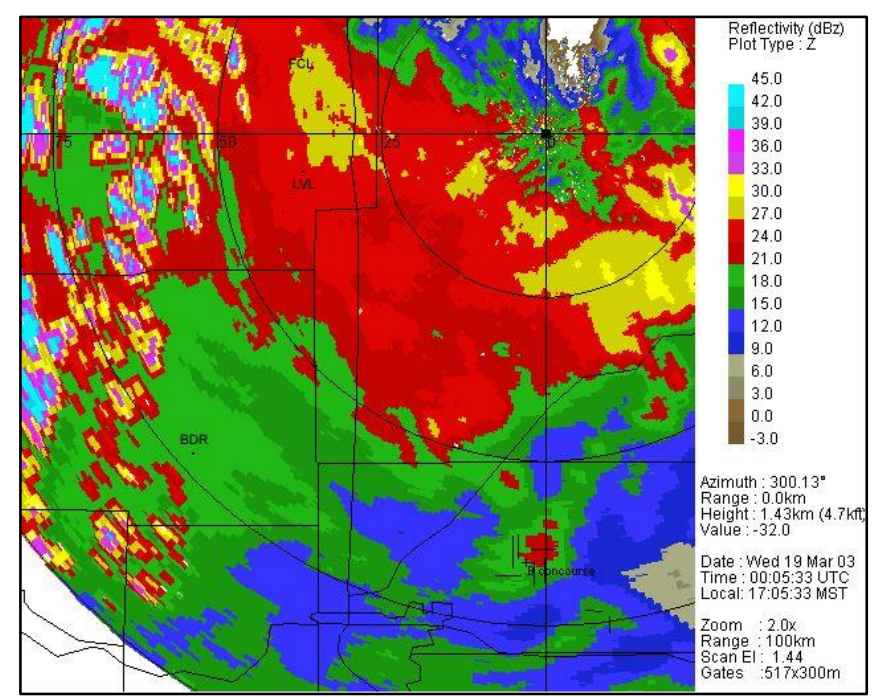

Figure 16. CHILL reflectivity (dBZ) at 0005 UTC 19 March 2003 on the 1.44-km AGL (4725 ft) surface. County boundaries and major highways are shown in black. Range rings are incremented at $40-\mathrm{km}(25-\mathrm{mi})$ intervals.

and Rutledge (2011) for a more detailed description of S-band dual-polarization observations during this storm]. It was located at a height of just below $1 \mathrm{~km}$ AGL, extending from just west of the radar out to nearly $30 \mathrm{~km}$, and then tilting downward at its westernmost extent as the lower temperatures within the barrier jet-like feature were encountered. The linear signature was a manifestation of melting snowflakes (Herzegh and Jameson 1992) which moved eastward with time as colder air built up against the Rocky Mountain barrier. As a result for later storm periods (after 1200 UTC 18 March), the melting zone was located east of the CHILL radar (during the intermittent precipitating periods) and the site itself was experiencing intermittent snowfall.

The CHILL-derived reflectivity analyses for 1.44km AGL (4425 ft) at 0005 UTC 19 March (Fig. 16) showed significant reflectivity associated with very heavy snowfall over eastern Larimer County, southwestern Weld County, and eastern Boulder County - west and south of the radar. Reflectivities of $30 \mathrm{dBZ}$ were common in the Loveland/Fort Collins region, just east of the foothills. Animation of the data showed that most of the precipitating features were quasi-stationary. This heavy precipitation was produced primarily by uplift over the relatively cool, stable air associated with the north-south oriented cold dome (see Fig. 12b and previous discussion). Considering the location of the more persistent large reflectivity zones, the surface and profiler
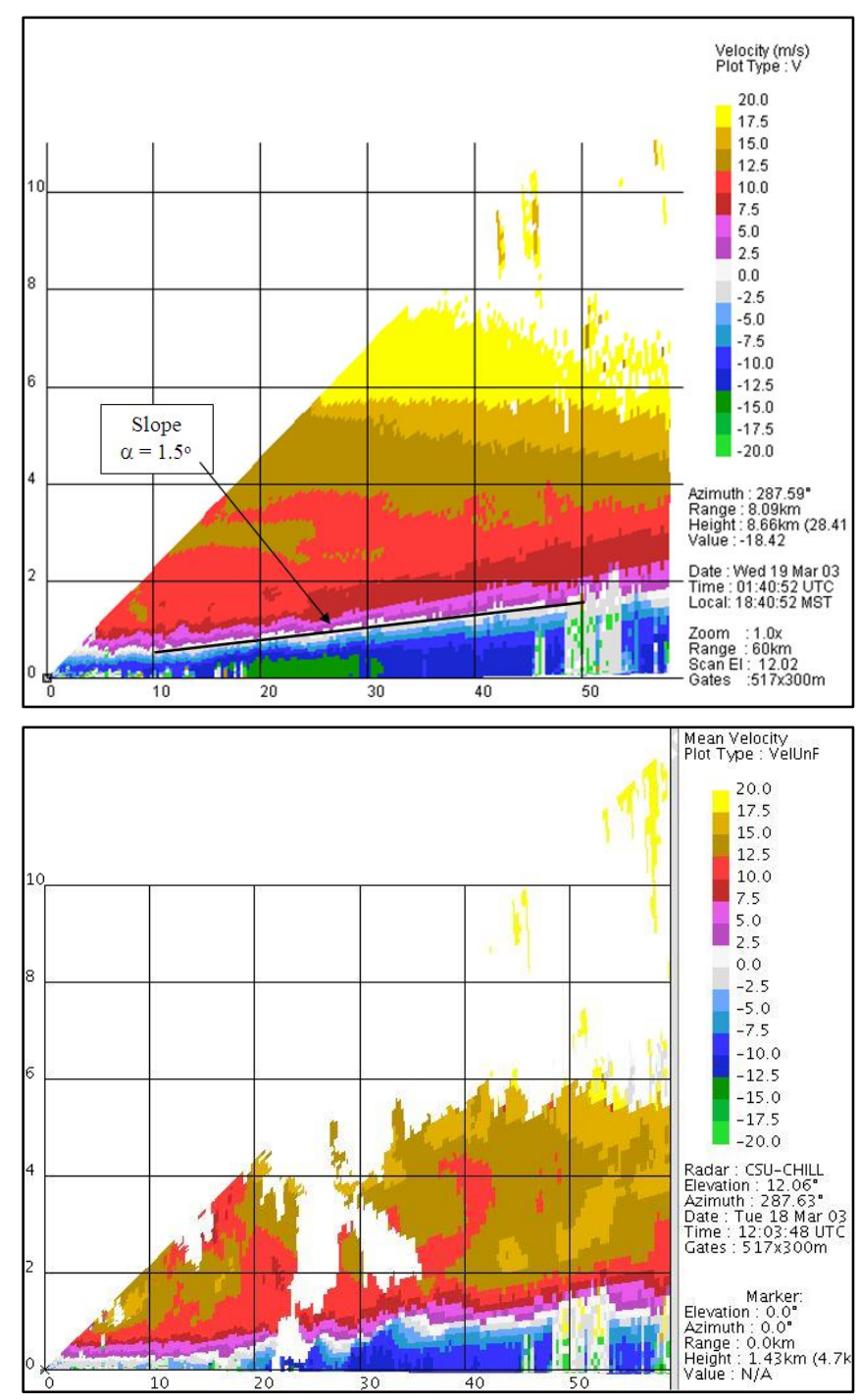

Figure 17. CHILL RHI velocity $\left(\mathrm{m} \mathrm{s}^{-1}\right.$, azimuth $288^{\circ}$ ) at (a, top) 0141 UTC 19 March and (b, bottom) 1204 UTC 18 March 2003. For both panels, radar location is at lower-left $(0,0)$ on the horizontal and vertical axes. Negative values denote flow towards the radar. Scales are marked in $\mathrm{km}$ both horizontally and vertically.

observations, and the Eta-derived forecasts discussed previously, the CHILL location marked the approximate eastward extent or onset of significant cold-air damming-induced uplift at this time. Other high-reflectivity zones of cellular appearance moving westward were located east of the radar and likely were associated with upright convection. This scenario of transient enhanced reflectivity features, primarily east of the radar, and larger more persistent features west of the radar, was common throughout much of the heavily precipitating storm periods (generally 2100 UTC 17 March through 0600 UTC 19 March; see Fig. $3 \mathrm{~b}$ and Table 1$)$. 
Confirmation of this scenario, and more evidence for the fact that the cold dome was wedge-shaped, sloping (laterally) upward to the west, is shown in Fig. 17a. This figure presents a $288^{\circ}$-azimuth RHI of radial velocity at 0140 UTC 19 March and is representative of the dammed scenario during the mature part of the storm evolution. Note the location of the terrain features (foothills) at $\sim 45-55-\mathrm{km}$ range; these were small reflectivity anomalies that extended upwards to near 2-km AGL (3.5-km MSL). An area of incoming velocities, generally from 7.7-12.9 $\mathrm{m} \mathrm{s}^{-1}(15-25 \mathrm{kt})$, characterized the lowest $0.75-1.5 \mathrm{~km}$ of the atmosphere, and this was the component of strong northerly flow; winds at the surface in this region were oriented $\sim 340-360^{\circ}$ (Fig. 10a). The core of the barrier jet-like feature was centered about $25 \mathrm{~km}$ west of the radar and $20-25 \mathrm{~km}$ east of the foothills at this time. The upper portion of the northerly flow layer was sloped upwards towards the mountains at $\sim 1.5^{\circ}$ for this azimuth in the $10-50-\mathrm{km}$ range and was $2-\mathrm{km}$ deep in the vicinity of the foothills. The lateral upward slope of the cold air has been noted in other Front Range storms (Marwitz and Toth 1993), United States East Coast storms (e.g., Bell and Bosart 1988), and Wasatch Range storms (Cox et al. 2005).

Above the northerly flow layer, the winds rapidly veered with height and became strong from the east by 0140 UTC 19 March (also see Fig. 8). The easterly flow advected the moist, conditionally unstable air mass, and it was rising due to both synoptic forcing and uplift over the relatively cooler and statically stable air mass associated with the barrier jet-like wedge. Uplift of the moist air mass flowing towards the west over the cold dome would produce a general ascent of $\sim 0.4 \mathrm{~m} \mathrm{~s}^{-1}$, based on the observed geometric slope of the upper portion of the barrier jet and the observed easterly winds at $700 \mathrm{mb}$ of about $15 \mathrm{~m} \mathrm{~s}^{-1}$ $(30 \mathrm{kt})$ at this time. This scenario assumed the stable layer at the top of the northerly flow essentially served as an upslope path for the incoming midlevel easterly flow, and that the shape of the wedge was maintained. For about 12 hours earlier (Fig. 17b), the dynamic scenario was similar but the depth of incoming velocity for the $288^{\circ}$ azimuth was significantly shallower and the incoming flow weaker.

A few hours later (0504 UTC 19 March) still during heavy snowfall along the Front Range, derived streamlines and conventional reflectivity at a fixed Cartesian height $(0.9 \mathrm{~km}$ above the radar) are shown based on the dual-Doppler analysis of the overlap regions of the CHILL and Pawnee radars, with "C"

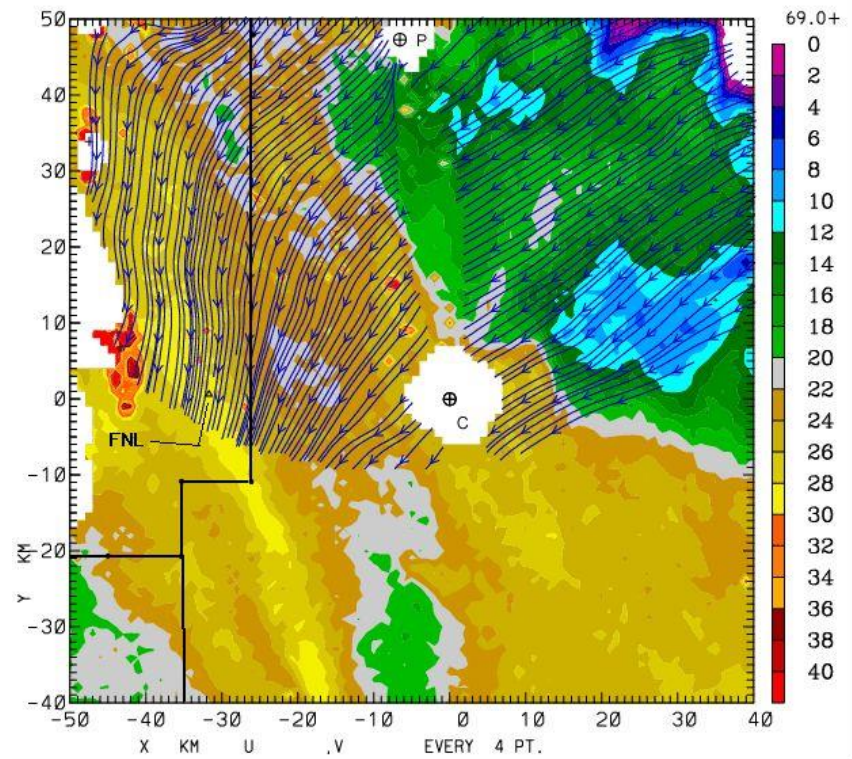

Figure 18. Dual-Doppler-derived streamlines and reflectivity (dBZ) at approximately $0.9 \mathrm{~km}$ above the ground, at 0504 UTC 19 March 2003. Data derived from the CHILL ("C") and Pawnee ("P") radar scans. "FNL" denotes the location of the Fort Collins/Loveland airport. Heavy black lines are county boundaries. Reflectivity anomalies in the foothills of Larimer County represent the higher foothills themselves.

and "P" denoting the radar locations, respectively (Fig. 18). This analysis plane sliced through the north-south oriented cold air dome, which was shown previously to have a lateral slope upwards to the west. Note the gradual backing in wind direction as one progressed westward from the eastern plains to the foothills region. The low-level northerly flow encompassed much of the area west of the radar. Surface wind speeds (not shown) were generally $5-10 \mathrm{~m} \mathrm{~s}^{-1}(10-20$ $\mathrm{kt})$ in the east-northeasterly flow over the plains, and $7.5-15 \mathrm{~m} \mathrm{~s}^{-1}(15-30 \mathrm{kt})$ just east of the foothills in the northerly flow at this time. The available Eta-model predictions (12- and 18-h forecasts) showed easterly flow at $7.5-10 \mathrm{~m} \mathrm{~s}^{-1}(15-20 \mathrm{kts})$ at the $1-\mathrm{km}$ level over the plains at this time. Significant reflectivity was confined to areas west and south of CHILL and Pawnee, with $\geq 25 \mathrm{dBZ}$ common in areas over and just east of the foothills. While the generally enhanced reflectivity to the west and southwest of the radar was consistent with damming-induced uplift, the heterogeneous reflectivity field in Fig. 18 clearly showed that the precipitation rate at any given time and location would likely be dominated by local storm dynamics or convection, and precipitation banding. One major band of enhanced reflectivity over and just west of the radars was oriented $330^{\circ}$, and a second of 


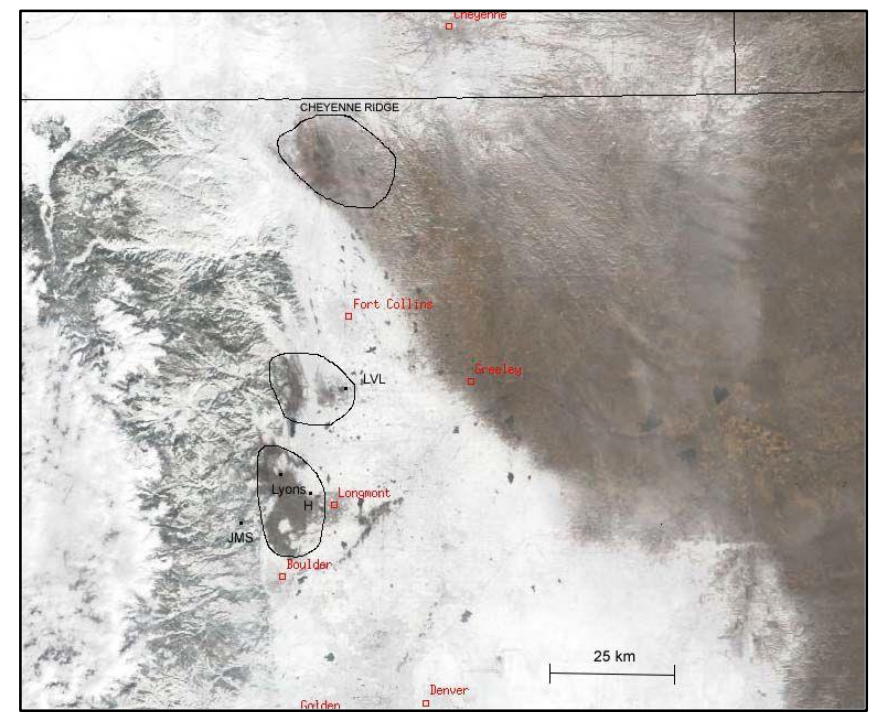

Figure 19. Moderate Resolution Imaging Spectroradiometer (MODIS) 3-channel true-color composite image on 22 March 2003, taken on a clear day three days after the conclusion of the storm. Complex patterns on the west side are timbered and canyon areas in mountainous regions. Annotated, darker areas just south of the WY state line, southwest of Fort Collins, and west of Longmont are locations where much less snow accumulation occurred. Additional locations shown include: Jamestown (JMS), Hygiene $(\mathrm{H})$, and Loveland (LVL). [Source of imagery: NASA and Scott Bachmeier of the Cooperative Institute for Mesoscale Meteorological Studies.]

similar orientation was just east of the foothills. These bands likely owed part of their existence to smallerscale processes, not addressed in this study. Overall, however, this Cartesian analysis is consistent with the interpretation of the CHILL radial velocity signature of a laterally sloped barrier jet-like feature topped by veering winds with height.

Figure 19 presents a satellite snapshot of this region a few days after the storm that illustrates some of the mesoscale variations in snowfall. Some melting had occurred by this time (daytime maximum temperatures were reaching $5-10^{\circ} \mathrm{C}$ during the $21-22$ March period over northeastern Colorado). A northwest-southeast-oriented snow/no-snow boundary reached from north of Fort Collins near the Wyoming border all the way to the plains directly east of Denver; this boundary was over $250 \mathrm{~km}(\sim 150 \mathrm{mi})$ in length (also see Fig. 3a). The northwestern portion of this boundary was north-northwest of Fort Collins, just south of the Wyoming border (on the south end of the northernmost circled region in Fig. 19). The portion of the boundary beginning $50-75 \mathrm{~km}$ south of the Cheyenne Ridge area generally represented the rain/snow demarcation. As noted earlier, temperatures at the height of the storm were well above freezing on Colorado's eastern plains (e.g., $6^{\circ} \mathrm{C}$ or $42.8^{\circ} \mathrm{F}$ at AKO at 0000 UTC 19 March at an elevation of about 1435 $\mathrm{m}$ or $4700 \mathrm{ft}$ ), where significant rain fell during this storm. AKO is located well east of the region shown in Fig. 19.

Some local minima in snowfall are noteworthy. The northernmost circled area in Fig. 19 was likely caused by a downsloping northerly flow off the Cheyenne Ridge, and resulted in reduced snowfall in the lee, as opposed to the occurrence of rain. A previous study (Wesley et al. 1995) documented snow reduction in this region due to northerly low-level flow during a shallow upslope situation. Elevations in the northernmost circled area of Fig. 19 are well above $1830 \mathrm{~m}(6000 \mathrm{ft})$, and temperatures were well below freezing beginning on the evening of 17 March, lasting through the rest of the storm. The downslope scenario in this region was supported by the numerical simulations discussed in the next section. Farther south, the eastward extension of the rain/snow boundary in Fig. 19 appeared to represent the cooling effects of rising terrain and associated upslope flow for northerly winds south of the Platte Valley, ascending the Palmer Divide.

Two other major features are annotated in Fig. 19: a small snow-free zone in the Lyons (elevation $1635 \mathrm{~m}$ or $5360 \mathrm{ft}$ ) and western Longmont vicinity just north of Boulder, and another smaller snow-free zone just west of Loveland. These minima were corroborated in the snowfall analysis in Fig. 3a. Examination of a detailed terrain dataset of this region (Fig. 20) lends some insight into the probable cause of these minima. The two annotated regions are the primary zones east of the foothills which experience downslope-induced low-level warming in a northerly flow regime. The northern region is located west of Loveland, and the southern region is between Lyons and Hygiene. They correlate well with the storm total snow measurements (Fig. 3a) and post-storm visible satellite imagery (Fig. 19). This will be investigated further in the following section.

\section{Model simulations of the complex wind and precipitation distribution}

In order to complement the analyses of observations and National Center for Environmental Prediction (NCEP) models, mesoscale model simulations were carried out in this study with the primary intent of examining the mechanisms for the 
observed fine-scale snowfall distribution in this area of complex terrain. The Pennsylvania State UniversityNational Center for Atmospheric Research fifthgeneration Mesoscale Model (MM5; Grell et al. 1994) was run non-hydrostatically with a telescopic nest, initializing at 0000 UTC 17 March and running out to 84 hours, utilizing a sophisticated microphysical scheme (Reisner et al. 1998). Figure 21 shows the grid configuration for the MM5 simulations over the western United States. The innermost grid spacing was set at $1 \mathrm{~km}$ and each successively larger grid was setup such that the grid spacing ratio was $3: 1$. There were 43 vertical levels in the domain. The operational Eta simulation $(12 \mathrm{~km})$ initialized at 0000 UTC 17 March supplied the MM5 boundary conditions, such that this simulation could have served an operational scenario given sufficient computing power. In addition to this high-resolution control run, a single additional simulation was completed that examined the sensitivity to minor changes in the small-scale terrain features discussed in section 3 .

\section{a. Basic simulations}

\section{1) COMPARISON WITH PRECIPITATION AND RADAR OBSERVATIONS}

Figure 22 shows the total model-predicted precipitation (liquid equivalent, LE) through 78 hours of the simulation, which spanned the entire lifetime of the event for the Front Range on a portion of the innermost grid. It should be noted that in both simulations and observations, all significant precipitation occurred in the area of interest after 1200 UTC 17 March (see Fig. 3b and Table 1), or after 12 hours into the simulations. Immediately evident in Fig. 22 were the LE maxima of $130-160 \mathrm{~mm}$ over the higher terrain [above $2440 \mathrm{~m}(8000 \mathrm{ft})$ in elevation; refer to Fig. 3a]. These maxima corresponded generally well with observations of LE for snowfall accumulation of $1.5 \mathrm{~m}$ or more (Fig. 3a) over central and southwestern Larimer County, and southern/ western Boulder County. LE was under-predicted over eastern Larimer County and much of Jefferson County as well as southern Gilpin County, where more than 1 $\mathrm{m}$ of snow and more than $125 \mathrm{~mm}$ LE occurred; the LE predictions in this region were $60-70 \mathrm{~mm}$. The precipitation pattern was generally well-represented by the model in much of the urban corridor, including the snowfall minima locations of the foothills/plains interface in Boulder and Larimer Counties discussed previously (Figs. 19 and 20). More specifically, a

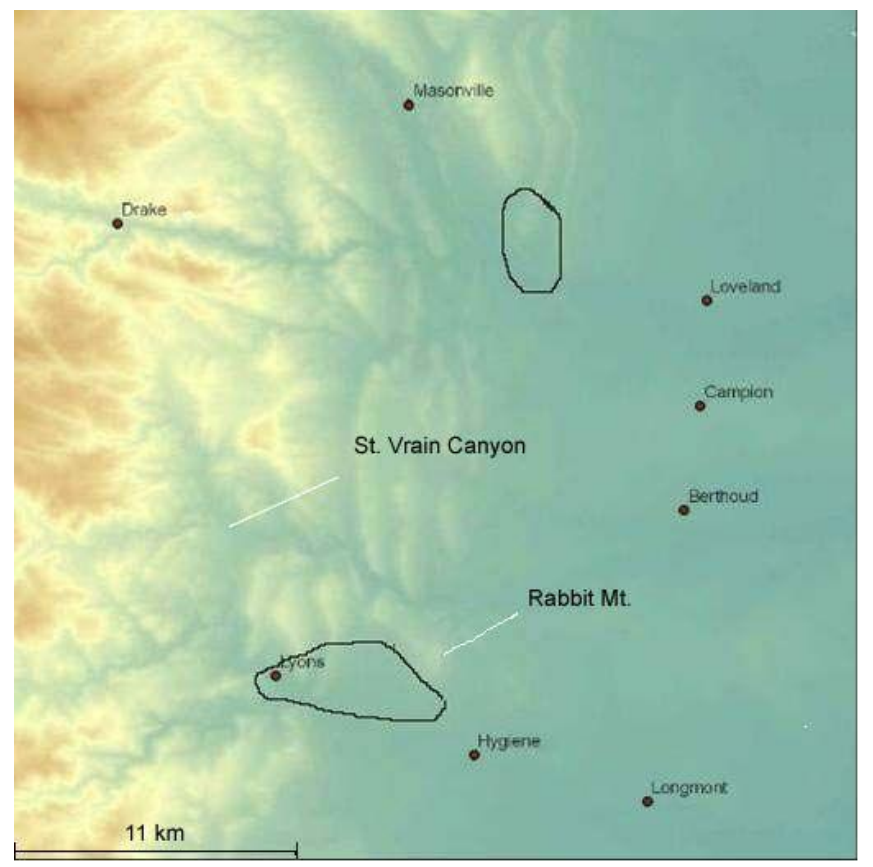

Figure 20. Relief (colored) from a 30-m dataset for the area of interest in the text discussion. Annotated areas are potential local downslope regions in a northerly surface-flow regime. Brown areas are higher-elevation regions $(>\sim 2.44 \mathrm{~km}$ or $8000 \mathrm{ft}$ ). For reference, Longmont's elevation is $1.52 \mathrm{~km}(4987 \mathrm{ft})$ and Drake is at $1.73 \mathrm{~km}(5676 \mathrm{ft})$. The top of the Rabbit Mt. ridge is $\sim 1.95 \mathrm{~km}$ $(6400 \mathrm{ft})$, or more than $\sim 0.3 \mathrm{~km}(\sim 1000 \mathrm{ft})$ above Lyons.

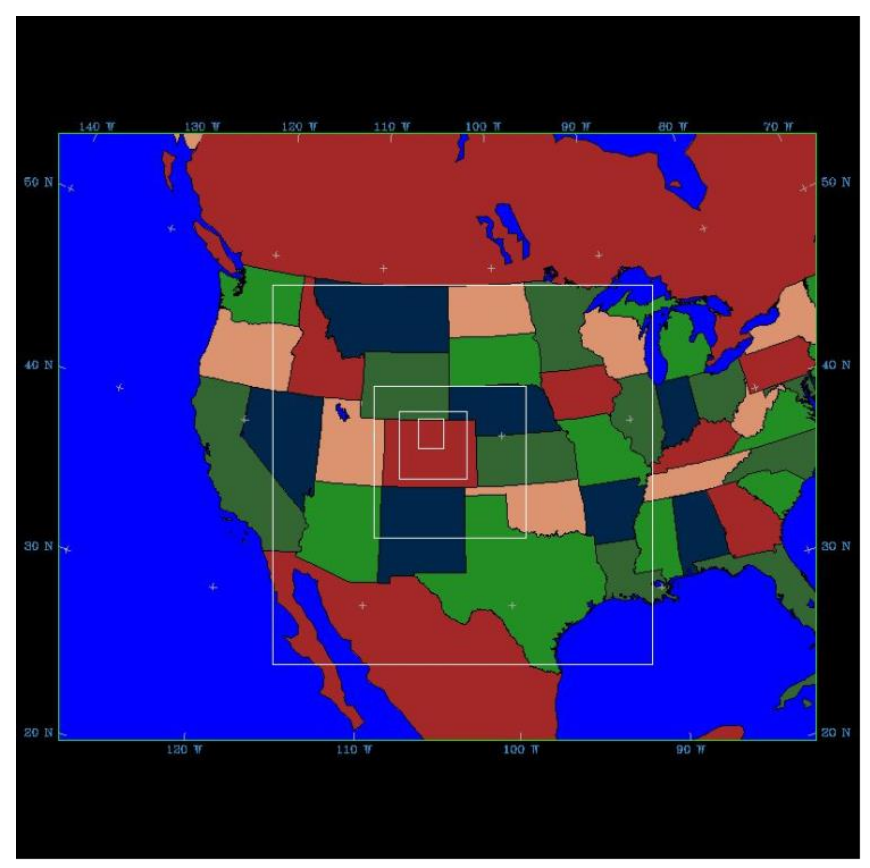

Figure 21. MM5 model nested-domain setup for the storm simulations, with the inner grids centered on northern Colorado.

distinct minimum was evident over the northern portion of the urban corridor near the Wyoming border 


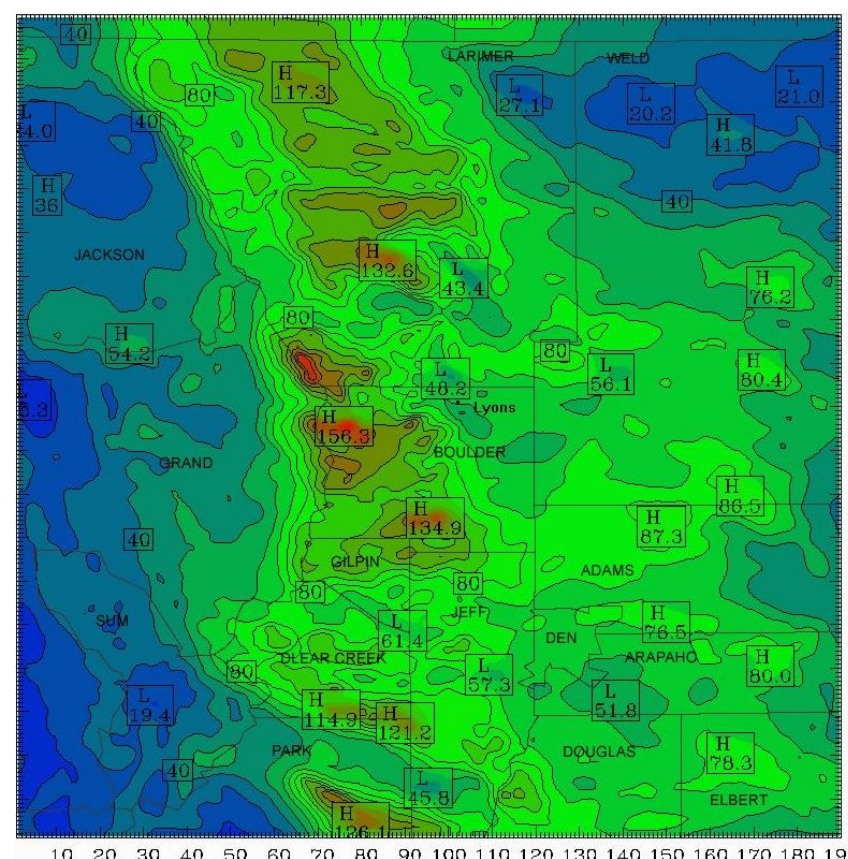

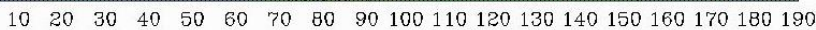

Figure 22. MM5-predicted total precipitation (mm) for 0000 UTC 17 March through 0600 UTC 20 March. Counties are labeled in capital letters. Axes are marked in $\mathrm{km}$ for horizontal distance. $\mathrm{H}$ and $\mathrm{L}$ denote relative precipitation maxima and minima. $1 \mathrm{~mm}$ of precipitation corresponds to $0.04 \mathrm{in}$.

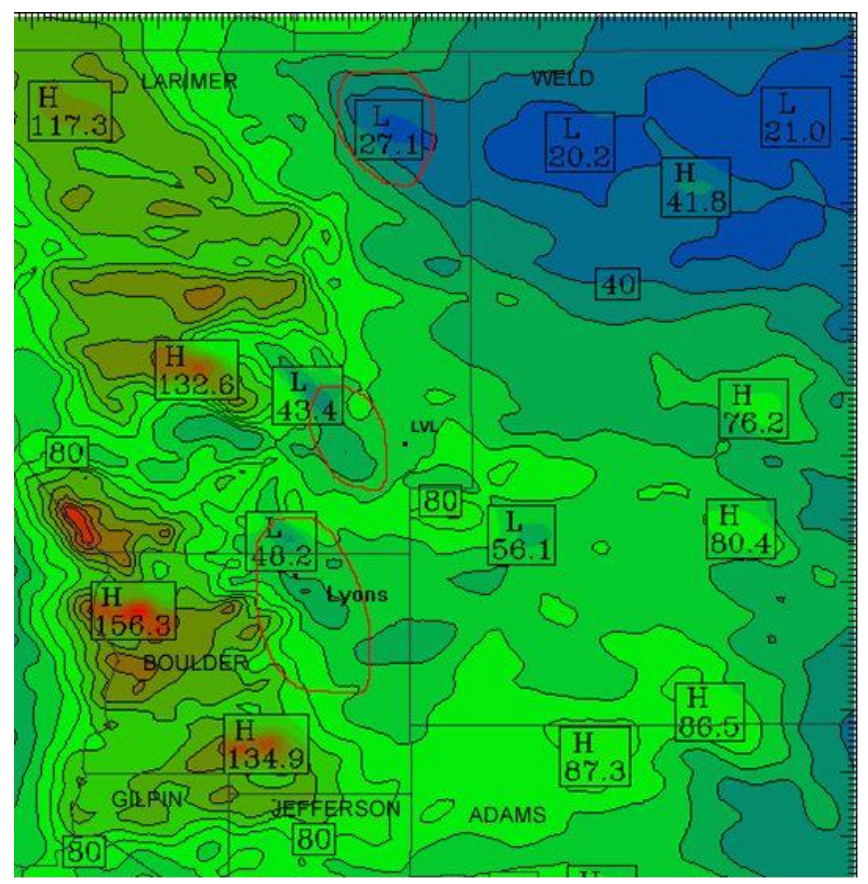

Figure 23. As in Fig. 22, but zoomed in on the area of interest, with annotated locations as discussed in text. The regions circled in red are the same as the snowfall minima shown previously in the satellite image (Fig. 19). The color scale is the same as that utilized in Fig. 22.

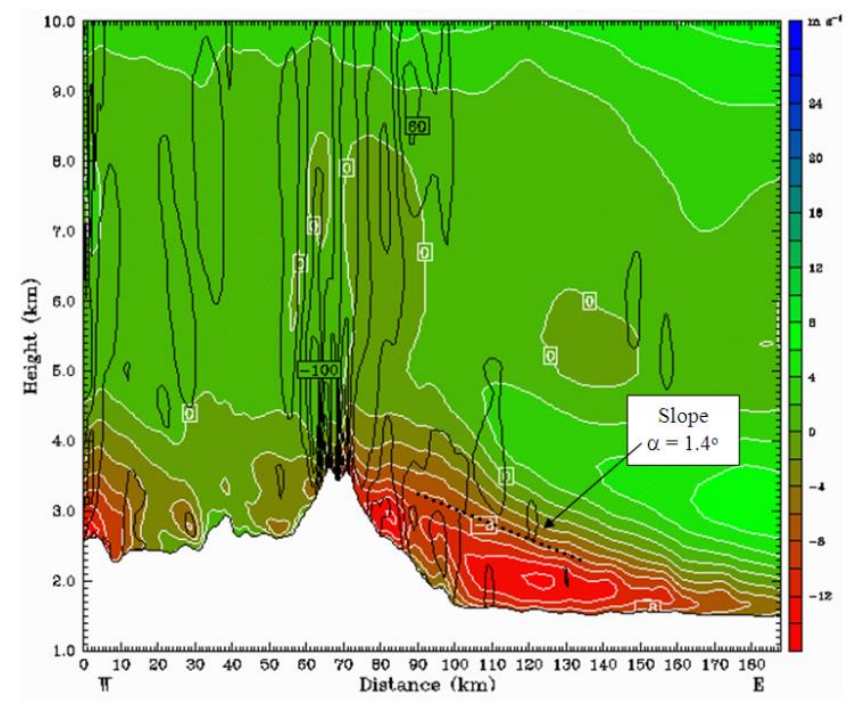

Figure 24. MM5-generated east-west vertical cross-section at $40^{\circ} \mathrm{N}$ latitude, $v$-component of wind $\left(\mathrm{m} \mathrm{s}^{-1}\right.$ contoured at $2-\mathrm{m} \mathrm{s}^{-1}$ intervals) at 1200 UTC 18 March 2003. Red areas represent $v$ components $<0$. Black contours represent omega values $\left(\mu \mathrm{b} \mathrm{s}^{-1}\right)$.

(Fig. 23), which matched up well with the observed minimum based on satellite data (Fig. 19). South of this region, precipitation varied from about $50-75 \mathrm{~mm}$ along the corridor, with local minima of less than 50 $\mathrm{mm}$ in the Lyons/Longmont vicinity and a small area just west of Loveland, again specified previously in the analysis of the satellite observations and in the detailed terrain shown in Fig. 20. In fact, the agreement of the locations of these minima is remarkable.

The simulation also recreates the general features of the barrier jet-like feature well, especially through the first 2 days of the storm (17-18 March). We made some comparisons of the dynamic features in the simulations and observations, and will now illustrate these at representative times. Figure 24 shows a vertical cross-section of the $v$-component of the wind at $40^{\circ} \mathrm{N}$ latitude for 1200 UTC 18 March. The core of the enhanced northerly flow was about $20 \mathrm{~km}$ east of the foothills, with a maximum in the northerly component of $15 \mathrm{~m} \mathrm{~s}^{-1}$ at about $300 \mathrm{~m}$ above the ground. Figure $17 \mathrm{~b}$ showed radar measurements at approximately the same time of the strongest incoming velocities located about $20 \mathrm{~km}$ east of the foothills, with these velocities in the $10-12.5 \mathrm{~m} \mathrm{~s}^{-1}$ range. Assuming horizontal uniformity in winds, and utilizing the observed low-level wind direction at that time, this would imply a north-northwesterly flow of about 17.5 $\mathrm{m} \mathrm{s}^{-1}$ at that time, or very similar to the MM5 prediction. The winds in Fig. 17b appeared to be 
maximized at or very near the ground. The deepening of the model-predicted northerlies as one proceeded westward was well-associated with the radar observations discussed previously in section 3. In fact, better agreement (both in the shape of the cold wedge and its extent) is noted in the MM5 than in the Eta simulations shown in Fig. 13. In section 3, we approximated the slope of the top of the cold dome (utilizing radar data) to be about $1.5^{\circ}$ at 0140 UTC 19 March and about $1.9^{\circ}$ at 1200 UTC 18 March; these values were representative through the period of strong cold-air damming (Table 1). Examining the slope of the simulated isentropes (not shown) at the top of the stably stratified region and the $v=-8 \mathrm{~m} \mathrm{~s}^{-1}$ contour in the simulations (Fig. 24), we find a mean slope of $1.4^{\circ}$ with slightly steeper values located on the west side of this region and slightly shallower values on its eastern side.

While high-resolution numerical weather prediction results should be interpreted with care for a variety of reasons, we believe that the favorable comparisons with observations in this case study are further proof of the value of this effort when carefully executed in the production of operational forecasts for the public (see also Poulos et al. 2002).

\section{2) SNOWFALL MINIMA}

Recall that the three areas of snow accumulation minima, as determined by satellite data and snowfall analyses, were noteworthy (Figs. 3a, 19, and 20). The northernmost area near the Wyoming border likely owed its existence to reduced precipitation as northerly downslope flow exited the Cheyenne Ridge region, which is centered along the Wyoming border. This mechanism is clearly borne out by the MM5 precipitation simulations (see the local minimum of 27 $\mathrm{mm}$ of total precipitation in the area of interest in Fig. 23) and the low-level winds and relative humidities predicted in that region during the peak of the storm (Fig. 25). Northerly, downslope winds at $10-15 \mathrm{~m} \mathrm{~s}^{-1}$ $(20-30 \mathrm{kt})$ were creating locally sub-saturated conditions over extreme northeastern Larimer County at 0600 UTC 19 March, with surface relative humidity below $80 \%$ in the model. These features characterized the period of model-predicted heavy precipitation.

In Fig. 25, it is apparent that at the peak of the storm the model was predicting near-saturated conditions at the surface for the Loveland-west and Lyons-Hygiene areas; but in Fig. 23 the total precipitation amounts do clearly show minima in these

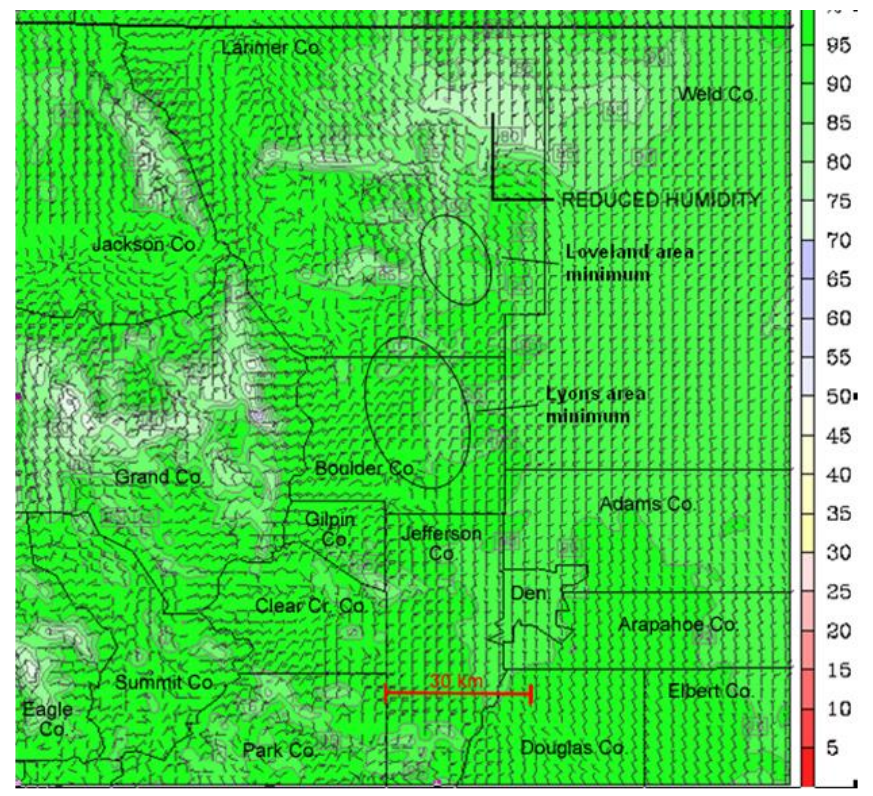

Figure 25. MM5-predicted surface winds $\left(\mathrm{m} \mathrm{s}^{-1}\right)$ and relative humidity (colored in \%) for 0600 UTC 19 March. The lighter green areas represent those with lower relative humidity values (note the marked area less than $80 \%$ just to the lee of the Cheyenne Ridge). The heavy black line near the upper portion of the figure is the Wyoming border. County boundaries are shown as thin black lines.

two regions. The precipitation values are $20-40 \%$ less than representative surrounding areas at similar elevations. The saturated conditions are located in an area of strong synoptic upward motion. As noted previously, relatively warmer surface temperatures early in the storm along the urban corridor caused some of the precipitation initially to fall as rain. At Lyons, the changeover to snow was delayed compared to other Front Range locations at similar elevation. Also, local observers in Lyons noted much wetter snowfall during most of the storm compared to surrounding areas, based on CoCoRaHS reports. Figure 26 shows representative model-predicted surface temperatures at (a) 1200 UTC and (b) 1800 UTC 18 March (note that lowest-level winds are included for the latter plot). The relatively warm pocket of air $\left(0.5-1^{\circ} \mathrm{C}\right.$ or $\left.0.9-1.8^{\circ} \mathrm{F}\right)$ located over northeastern Boulder County, just southeast of the Lyons area, is notable at both times and corresponds to the location of the snow minimum shown in Fig. 19. Another relatively warm pocket is evident, again, west of Loveland, extending just into the foothills with temperatures above $0.5^{\circ} \mathrm{C}$ at 1200 UTC and above $2.5^{\circ} \mathrm{C}$ at 1800 UTC. Both warm pockets corresponded to the local model-predicted precipitation minima. Both of these regions also experienced significantly 


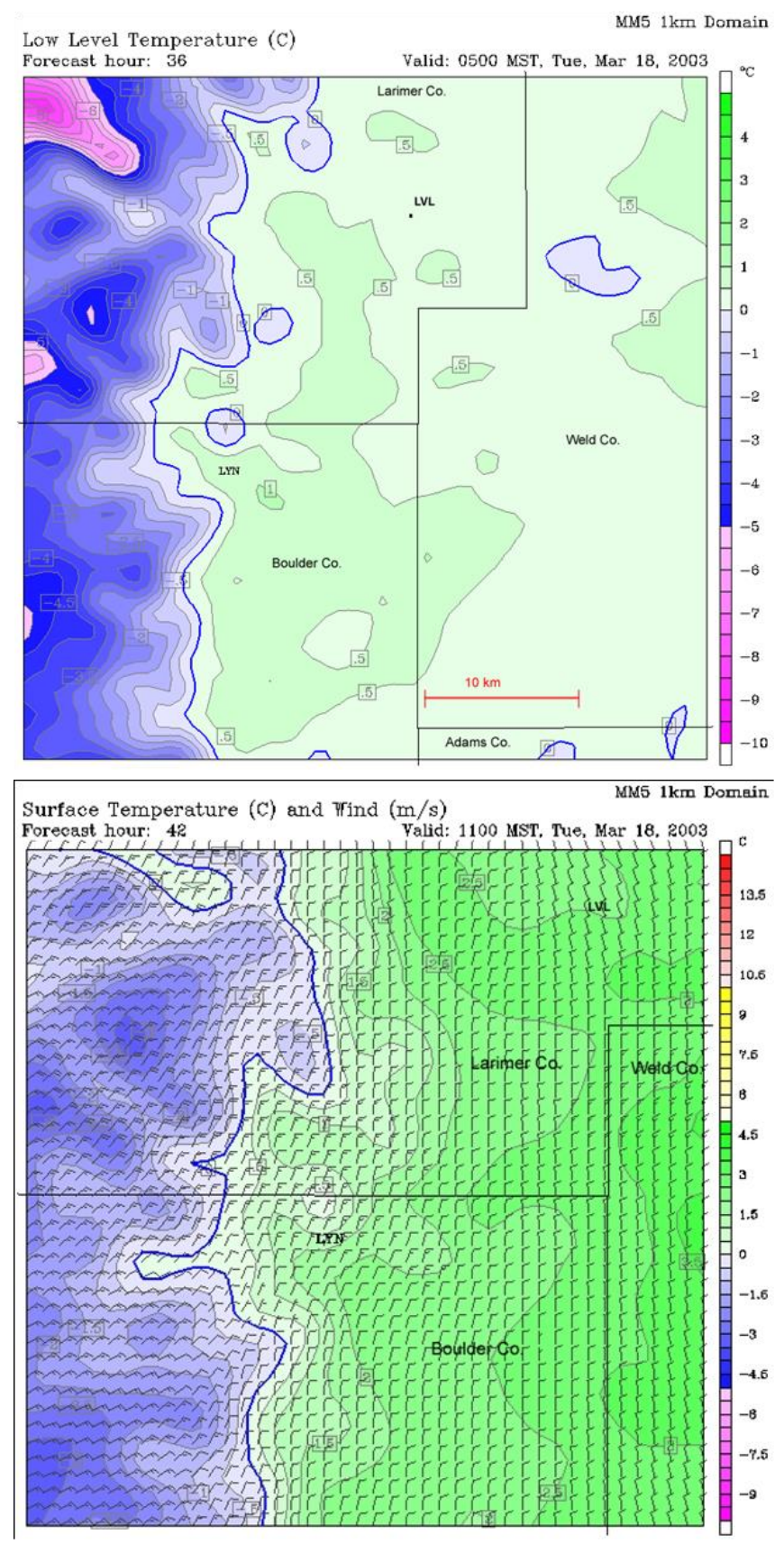

Figure 26. MM5-predicted temperature $\left({ }^{\circ} \mathrm{C}\right)$ at the lowest model level for (a, top) 1200 UTC 18 March 2003 and (b, bottom) 1800 UTC 18 March. Winds $\left(\mathrm{m} \mathrm{s}^{-1}\right)$ are included in (b). LYN denotes the location of Lyons, CO, and LVL is Loveland. A temperature of $1^{\circ} \mathrm{C}$ corresponds to $1.8^{\circ} \mathrm{F}$ and each $1^{\circ} \mathrm{C}$-interval represents $1.8^{\circ} \mathrm{F}$.

less snowfall than the immediately surrounding areas at very similar, and in some cases slightly higher, elevations - as discussed previously (Figs. 3 and 19); these were located within the northerly surface flow regime associated with the barrier jet. Exactly how well the observed liquid precipitation amounts matched the model-predicted reductions is unknown, due both to varying spatial resolution of measuring locations as well as large uncertainties in measuring the liquid equivalent itself — due mostly to wind issues (Doesken and Judson 1997).

As discussed previously, close examination of nearby terrain features (Fig. 20) revealed that these areas of interest are located just south of subtle east-west-oriented terrain features, or protrusions of ridges eastward into the plains. Importantly, close examination of Figs. 4 and 20 shows that for the overall urban corridor/foothills interface, these two terrain features are unique (i.e., similar features in scale and in the context of east-west orientation). Furthermore, they do not occur along the corridor anywhere else north of the Palmer Divide region, which is located approximately $50-\mathrm{km}$ south of Denver, until one approaches the Cheyenne Ridge well to the north. Likewise, no other remarkable snow minima were observed along this corridor. Given the observations and model results discussed to this point, we conclude that the local precipitation hypergradients (Figs. 3a, 19, and 23) appear to have been generated by the interaction of local topographic east-west protrusions with the long-lived northerly flow.

\section{b. Terrain sensitivity simulations}

In order to further investigate local terrain influences on the snowfall distribution, the MM5 was run with the same initial conditions and model physics described above but with one difference-manually altered ground elevations that eliminate the east-west ridges which may have contributed to local snowfall minima. Elevations for a portion (including all of the modified features) of the innermost grid are shown for the control run (Fig. 27a) and for the sensitivity test (Fig. 27b). Only the eastward protrusions of ridges just north of Lyons and northwest of Loveland were removed, as evident in the smoothed 1600-1800 m elevation contours, to examine the potential role of these features in the simulated precipitation evolution. If our hypothesis regarding the microscale role of these terrain features in affecting snowfall is correct, then one would expect to find the following in the affected areas: 1) greater precipitation, 2) lower temperatures, and 3) snow rather than mixed precipitation or rain. The following discussion presents model results for one particular time during the storm, but these results are representative of the simulations with altered terrain. 

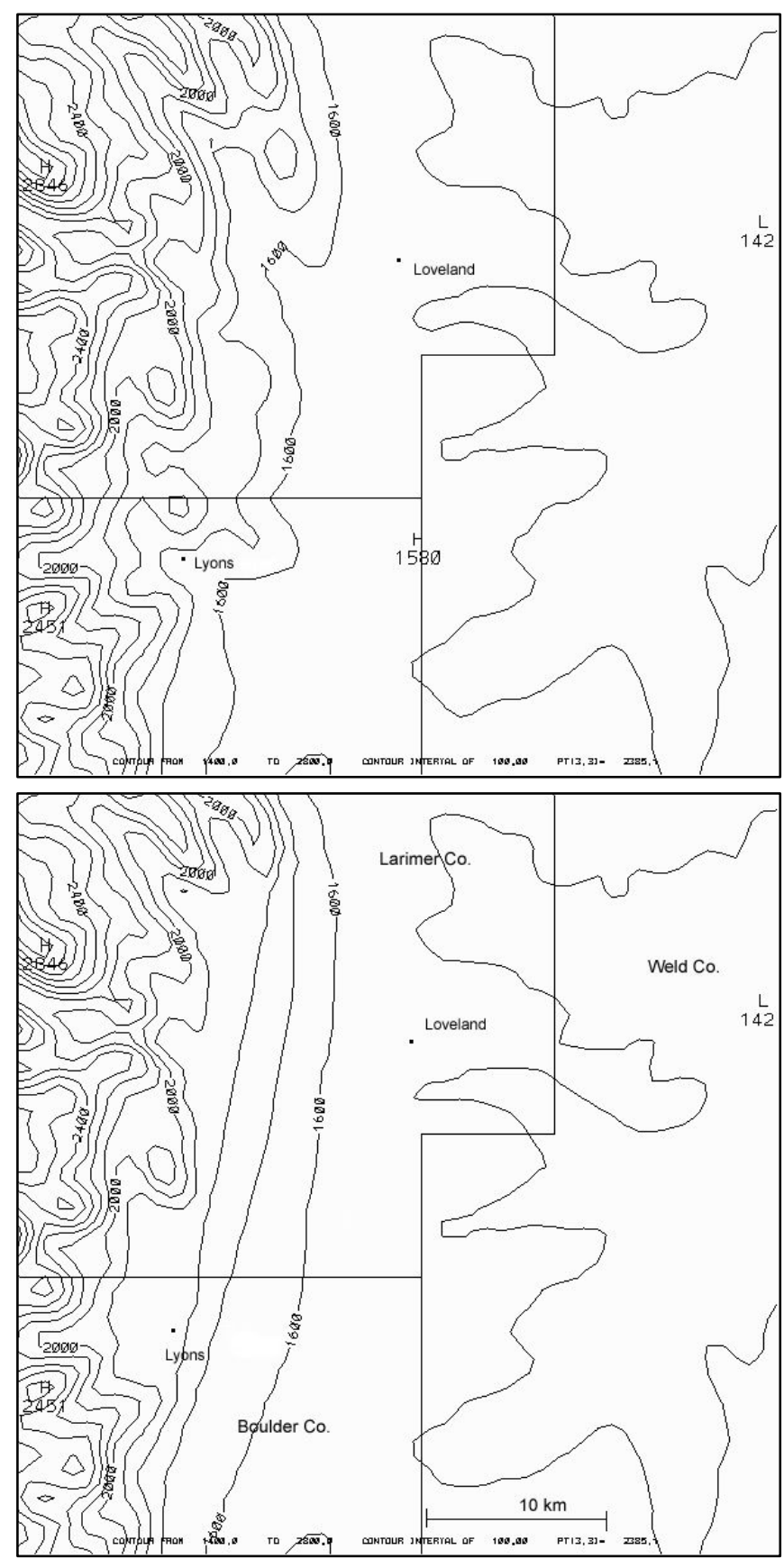

Figure 27. Terrain heights $(\mathrm{m})$ in the innermost grid, zoomed in on the Lyons, CO, vicinity for (a, top) the control run and (b, bottom) the terrain sensitivity simulation.

Regarding the role of the terrain features on surface temperature, Fig. 28 illustrates a representative sample of the influence on model lowest-layer temperature by the altered terrain. Results from the model control run are shown in Fig. 26b, while those from the sensitivity test are seen in Fig. 28. The removal of the small-scale ridges has indeed removed a warm pocket of air just south of the Lyons location

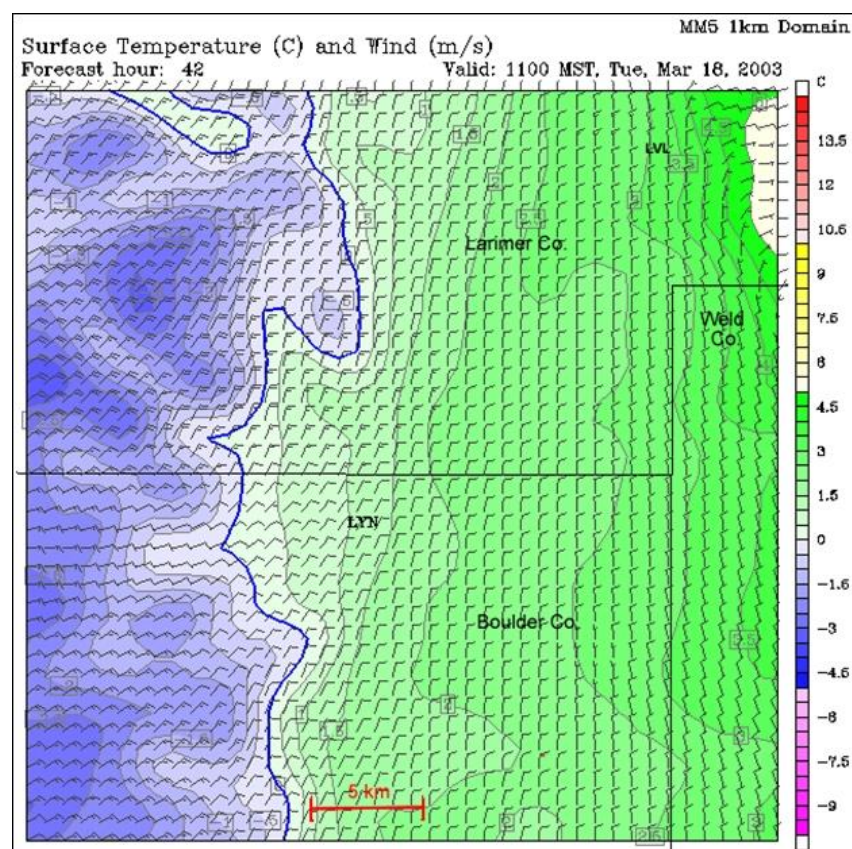

Figure 28. MM5 sensitivity simulation of surface temperature $\left({ }^{\circ} \mathrm{C}\right)$ and winds $\left(\mathrm{m} \mathrm{s}^{-1}\right)$ at 1800 UTC 18 March 2003. Locations shown are Lyons (LYN) and Loveland (LVL), CO. A temperature of $1^{\circ} \mathrm{C}$ corresponds to $1.8^{\circ} \mathrm{F}$ and each $1^{\circ} \mathrm{C}$-interval represents $1.8^{\circ} \mathrm{F}$.

evident in the control run (Fig. 26b). Note that surface temperatures in the $1.5-2.0^{\circ} \mathrm{C}$ range are present in and west of the Lyons area in Fig. 26b; these temperatures are about $1.0^{\circ} \mathrm{C}$ higher than those in the same locations shown in Fig. 28. The same difference is noted in the area of interest just west of Loveland (also about $1.0^{\circ} \mathrm{C}$ or $1.8^{\circ} \mathrm{F}$ lower in the terrain sensitivity test). Interestingly, winds exhibit a bit more of an easterly component in the Lyons area for the sensitivity run. Regardless, the northerly low-level flow in general would imply local downslope conditions south of the eastward terrain protrusions (for the control run in this case).

The effect of small-scale warming, induced by terrain features, is important, as it could be significant in any storm where surface temperatures are near $0^{\circ} \mathrm{C}$. As stated earlier, the changeover to snow was locally delayed in the Lyons area, and subsequent snowfall was observed to be wetter than that in surrounding regions at similar elevations. However, note also that in the simulation there is a localized region of higher temperatures and easterly winds in the sensitivity run over extreme eastern Larimer County (northeastern corner of Fig. 28) that apparently does not owe its existence directly to terrain effects. The cause of this feature is not known at this time. 
Incorporation of a sophisticated microphysical scheme (Reisner et al. 1998) in the MM5 simulations enabled some important interpretation of the effect of the modified terrain on local precipitation types. Figure 29 shows the model predictions of precipitation type at the representative time of 1800 UTC 18 March. Results from the model control run are shown in Fig.29a, while those from the sensitivity test are seen in Fig. 29b.

Note that regions of liquid precipitation predicted over the Lyons area, and also just west of Loveland, are removed in the sensitivity run-replaced by areas of predicted snow or mixed precipitation. This result is perhaps surprising given the relatively small size of the terrain features in question; but it is entirely in agreement with our expectation as to the effect of altering the terrain on local precipitation types, pointing again towards the importance of the relatively subtle eastward protrusions of terrain and the local surface temperatures. Whereas the impact around Lyons was consistent throughout the simulation, the ancillary changes to the precipitation type in other parts of Fig. 29 were not persistent and can be ascribed to run-to-run variability. Examination of modelpredicted total precipitation for the storm for the terrain-altered simulation (not shown) revealed slightly more precipitation as expected, but only on the order of 5\% in the two local areas of interest. The magnitude of the increase was significantly smaller than the observed anomalies shown in the observations (Fig. 3). Further investigation of model simulations would be required to lend more insight into this disparity. Recall that based on observations the precipitation type/ wetness issues may have played a more important role in creating the urban corridor snowfall minima than a general reduction in precipitation.

Overall, the model sensitivity experiments support our conclusion that local downslope conditions were the primary factor in the generation of the local precipitation hyper-gradients near Lyons and Loveland during this storm. In particular, the sensitivity tests support what was observed during this storm; minor topographic relief under the influence of barrierparallel winds induced by statically stable (blocked) flow can significantly alter local snowfall distribution when surface temperatures hover near freezing. More specifically, both the local observations available in this storm and the mesoscale model sensitivity experiments indicate that the temperature-induced precipitation type/wetness issue may have been a more

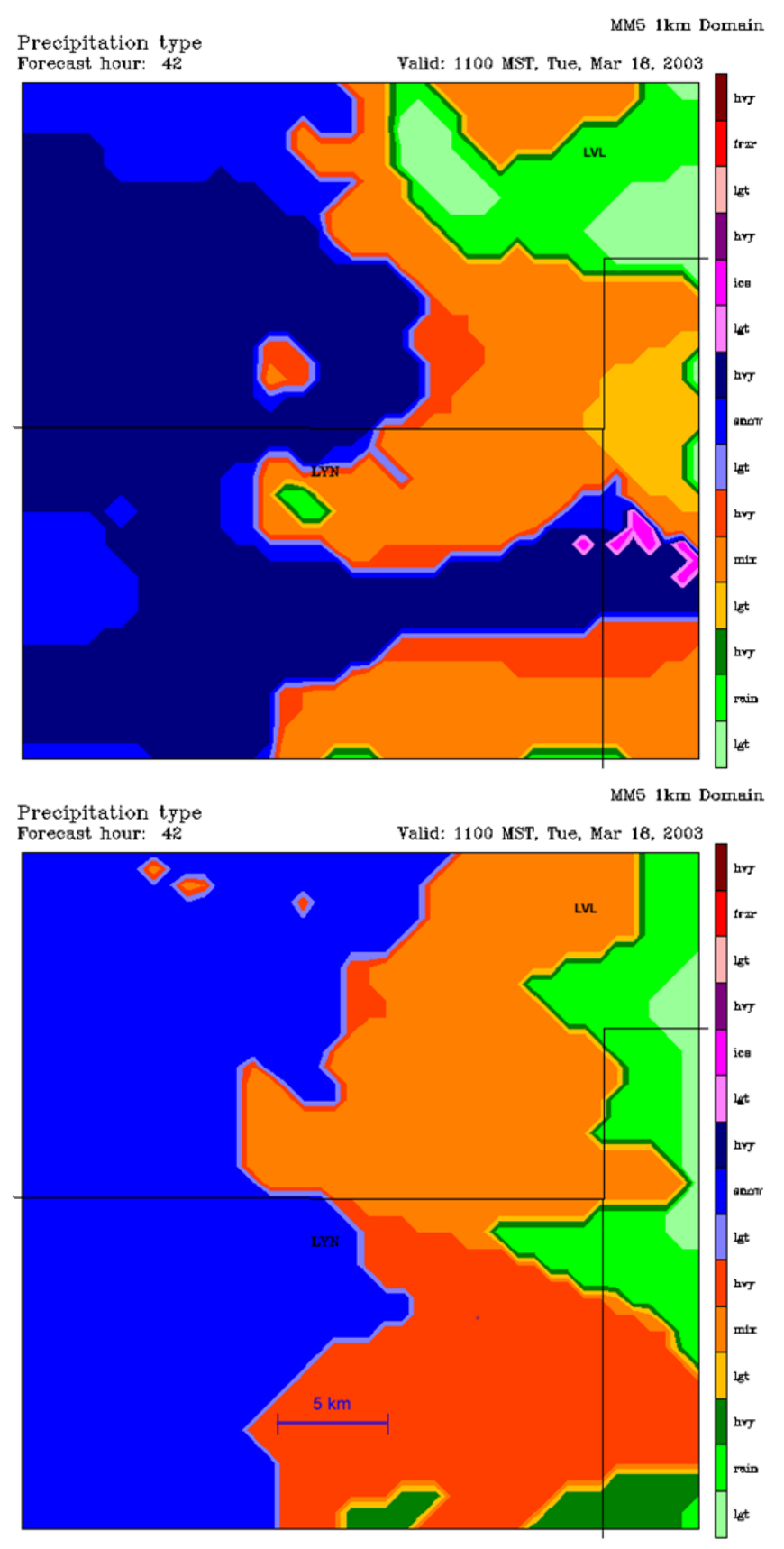

Figure 29. MM5 control (a, top) and sensitivity (b, bottom) simulations of precipitation type at 1800 UTC 18 March 2003. Green areas represent liquid precipitation, orange represents mixed precipitation, blue represents snow, and purple represents ice pellets.

important factor than simply the amount of precipitation.

\section{Summary and conclusions}

This case study has documented a synoptically intense and long-lived Front Range snowstorm that 
occurred during 17-19 March 2003, and in particular focused on the small-scale hyper-gradients of precipitation. Climatological data indicated that this storm produced precipitation amounts that occur on the order of once in 50-100 years over northern Colorado; foothill and mountain snowfall amounts exceeded $1.5 \mathrm{~m}$ over large areas and urban corridor amounts of $1 \mathrm{~m}$ or more were widespread. The storm crippled transportation systems and produced major structural damage, focused primarily on the Colorado Front Range urban corridor but extending well into the mountains.

The evolution of the synoptic conditions for the storm indicated the development of an exceptionally strong and deep closed low-pressure center over the southwestern United States. Associated with this was very strong easterly flow in the middle and upper layers of the atmosphere over the Front Range that persisted for 36 to 48 hours, and transported a deep air mass with anomalously high moisture content from the Great Plains and even the Gulf of Mexico directly into the area. The low itself moved eastward relatively slowly, so the deep upslope flow was able to persist through the period.

Associated with the strong, deep easterly flow was the development of a strong cold wedge and an embedded northerly barrier jet-like feature that persisted for more than 36 hours along the foothills and foothills-plains interface. Using observations from radars, wind profilers, radiosondes, and surface stations, as well as numerical simulations, an assessment of the three-dimensional structure of the barrier jet-like feature was made. The cold wedge and jet-like feature were dominant in terms of the urban corridor snowfall distribution in two ways. First, enhanced overrunning flow enabled very high precipitation amounts to develop just east of the primary terrain gradient associated with the foothills. Second, low-level cold advection produced by synoptic processes, and diabatic cooling produced by the melting of heavy snow induced by lift above the cold dome, led to a changeover of rainfall into snowfall over the urban corridor early in the storm, when synoptically a continuation of rainfall was indicated by most available numerical guidance. The changeover was permanent in nearly the entire urban corridor through the cessation of snowfall late on 19 March. We have confirmed the existence of a lateral upward slope of the statically stable cold wedge (towards the barrier) that enhanced overrunning, and an upper layer of the wedge characterized by strong vertical wind shear. We call the northerly flow regime "barrier jet-like" because blocking-induced northerly flow was a major factor in its development and wind speeds of $15-26 \mathrm{~m} \mathrm{~s}^{-1}(30-50 \mathrm{kt})$ were present; however, since a northerly surge and cold advection also were involved, and a consistent signature of an elevated wind maximum was not observed, the feature cannot simply be characterized as a classic barrier jet.

The immense forecast challenge associated with this storm was complicated by very strong horizontal hyper-gradients in snowfall that occurred just east of the Front Range foothills and rendered the impact on the public highly variable. Through a combination of mesoscale wind, temperature, and precipitation measurements, along with satellite observations and mesoscale modeling, it was shown that relatively modest terrain features played a major role in producing these gradients. In particular, in the Lyons vicinity and just west of Loveland, Colorado, relatively small eastward protrusions of terrain features created local pseudo-adiabatically warmed regions just to the south, due to the northerly wind environment. This led to slightly warmer conditions in those areas, local persistence of rain, rain mixed with snow, and more dense snowfall, as well as significantly less total precipitation. Urban corridor temperatures in general were near freezing through the period of heavy precipitation rates in this storm, increasing the precipitation-type sensitivity to locally warmed areas. The net result was drastically reduced snow depth in these two local regions that are (1) characterized by elevations slightly higher than those in the urban corridor to the east, and (2) located just downstream of relatively small east-west oriented topographic ridges.

The MM5 model simulations in this study were performed in quasi-realtime mode (i.e., the larger scale Eta-model predictions provided the boundary conditions). Given sufficient computing power, we envision these types of simulations, which captured the local precipitation minima and precipitation-type patterns relatively well, to be operational tools in the future. We also envision significant opportunities for further research, given sufficient instrumentation in the urban corridor, building on analyses of local terraininduced precipitation gradients. This research could also enhance operational expertise on the relative magnitudes of the influence of cold advection, blocking, and diabatic effects during cold-air damming situations. 
Acknowledgements. We thank UCAR (University Corporation for Atmospheric Research), NOAA, and the Meteorological Service of Canada for supporting this study. Nolan Doesken provided important insights regarding interpretations of the storm measurements. Matt Kelsch is thanked for analyzing the surface observations of liquid equivalent precipitation. Dr. Steve Rutledge provided access to CHILL radar data. CHILL is operated by Colorado State University and the National Science Foundation. Jim Steenburgh is thanked for consultation on microscale snowfall gradients, and Tammy Weckwerth for scientific interpretation of radar data. Rolf Hertenstein, Scot Rafkin, and Ben Bernstein provided key local surface observations in the Lyons vicinity. Dave Barjenbruch and Ed Szoke are thanked for assisting in the interpretation of model and observed data. Rick Koehler assisted in generating snowfall contour plots. Scott Bachmeier provided key high-resolution satellite data, and Dolores Kiessling provided important case study data. Heather McIntyre assisted in snowfall analyses. Tim Spangler provided storm observations in the Nederland vicinity. The National Renewable Energy Laboratory is thanked for providing surface observations at its NWTC (National Wind Technology Center) M2 Tower. Steve Deyo and Heidi Godsil assisted in the development of several graphical plots. NOAA provided the NEXRAD (Next Generation Weather Radar) imagery utilized in the study. We thank GIS (Geographic Information Systems) Coordinator Jennifer Boehnert at NCAR for the highresolution terrain dataset.

\section{REFERENCES}

Bailey, C. M., G. Hartfield, G. M. Lackmann, K. Keeter, and S. Sharp, 2003: An objective climatology classification scheme, and assessment of sensible weather impacts for Appalachian cold-air damming. Wea. Forecasting, 18, 641-661.

Bell, G. D., and L. F. Bosart, 1988: Appalachian cold-air damming. Mon. Wea. Rev. 116, 137-161.

Black, T. L., 1994: The new NMC mesoscale Eta Model: Description and forecast examples. Wea. Forecasting, 9, 265-278.

Bousquet, O., and B. F. Smull, 2003: Observations and impacts of upstream blocking during a widespread orographic precipitation event. Quart. J. Roy. Meteor. Soc., 129, 391-409.

Brunkow, D., V. N. Bringi, P. C. Kennedy, S. A. Rutledge, V. Chandrasekar, E. A. Mueller, and R. K. Bowie, 2000: A description of the CSU-CHILL National Radar Facility. J. Atmos. Oceanic Technol., 17, 1596-1608.

Colle, B. A., and C. F. Mass, 1995: The structure and evolution of cold surges east of the Rocky Mountains. Mon. Wea. Rev., 123, 2577-2610.
Cox, J. A. W., W. J. Steenburgh, D. E. Kingsmill, J. C. Shafer, B. A. Colle, O. Bousquet, B. F. Smull, and H. Cai, 2005: The kinematic structure of a Wasatch Mountain winter storm during IPEX IOP3. Mon. Wea. Rev., 133, 521-542.

Doesken, N., 2003: Just what the drought doctor ordered: A summary and observations of the March 17-20, 2003 snowstorm - A climatologist's view. Colorado Climate: Water Year 2003, 4 (1-4), 13-15. [Available online at ccc.atmos.colostate.edu/pdfs/wy2003.pdf.] , and A. Judson, 1997: The Snow Booklet: A Guide to the Science, Climatology, and Measurement of Snow in the United States. 2nd Ed., Colorado Climate Center, 87 pp.

Dunn, L., 1987: Cold air damming by the Front Range of the Colorado Rockies and its relationship to locally heavy snows. Wea. Forecasting, 2, 177-189.

1992: Evidence of ascent in a sloped barrier jet and an associated heavy-snow band. Mon. Wea. Rev., 120, 914-924.

Forbes, G. S., D. W. Thomson, and R. A. Anthes, 1987: Synoptic and mesoscale aspects of an Appalachian ice storm associated with cold-air damming. Mon. Wea. Rev., 115, 564-591.

Fritsch, J. M., J. Kapolka, and P. A. Hirschberg, 1992: The effects of subcloud-layer diabatic processes on cold air damming. J. Atmos. Sci., 49, 49-70.

Grell, G. A., J. Dudhia, and D. R. Stauffer, 1994: A description of the fifth-generation Penn State/NCAR Mesoscale Model (MM5). NCAR Tech. Note NCAR/TN-398+STR, 128 pp. [Available from National Center for Atmospheric Research, P.O. Box 3000, Boulder, CO 80307.].

Heffernan, E., and J. Marwitz, 1996: The Front Range blizzard of 1990. Part II: Melting effects in a convective band. Mon. Wea. Rev., 124, 2469-2482.

Herzegh, P. H., and A. R. Jameson, 1992: Observing precipitation through dual-polarization radar measurements. Bull. Amer. Meteor. Soc., 73, 1365-1374.

Kennedy, P. C., and S. A. Rutledge, 2011: S-band dual polarization radar observations of winter storms. $J$. Appl. Meteor. Climatol., 50, 844-858.

Loescher, K. A., G. S. Young, B. A. Colle, and N. S. Winstead, 2006: Climatology of barrier jets along the Alaskan coast. Part I: Spatial and temporal distributions. Mon. Wea. Rev., 134, 437-453.

Marwitz, J., and J. Toth, 1993: The Front Range blizzard of 1990. Part I: Synoptic and mesoscale structure. Mon. Wea. Rev., 121, 402-415.

Medina, S., B. F. Smull, R. A. Houze Jr., and M. Steiner, 2005: Cross-barrier flow during orographic precipitation events: Results from MAP and IMPROVE. J. Atmos. Sci., 62, 3580-3598.

Meyers, M. P., J. S. Snook, D. A. Wesley, and G. S. Poulos, 2003: A Rocky Mountain storm. Part II: The forest 
blowdown over the west slope of the northern Colorado mountains-Observations, analysis, and modeling. Wea. Forecasting, 18, 662-674.

Parish, T. R., 1982: Barrier winds along the Sierra Nevada Mountains. J. Appl. Meteor., 21, 925-930.

Pierrehumbert, R. T., and B. Wyman, 1985: Upstream effects of mesoscale mountains, J. Atmos. Sci., 42, 977-1003.

Poulos, G. S., D. A. Wesley, J. S. Snook, and M. P. Meyers, 2002: A Rocky Mountain storm. Part I: The blizzardKinematic evolution and the potential for highresolution numerical forecasting of snowfall. Wea. Forecasting, 17, 955-970.

Reisner, J., R. M. Rasmussen, and R. T. Bruintjes, 1998: Explicit forecasting of supercooled liquid water in winter storms using the MM5 mesoscale model. Quart. J. Roy. Meteor. Soc., 124, 1071-1107.

Richwien, B. A., 1980: The damming effect of the southern Appalachians. Natl. Wea. Dig., 5 (1), 2-12.

Schwerdtfeger, W., 1974: Mountain barrier effect on the flow of stable air north of the Brooks Range. Proc. 24th Alaskan Science Conference, Geophysical Institute, University of Alaska, Fairbanks, 204-208.

, 1975: The effect of the Antarctic Peninsula on the temperature regime of the Weddell Sea. Mon. Wea. Rev., 103, 45-51.
Szeto, K. K., C. A. Lin, and R. E. Stewart, 1988: Mesoscale circulations forced by melting snow. Part I: Basic simulations and dynamics. J. Atmos. Sci., 45, 1629-1641.

Weaver, J. F., 2003: An unusually heavy snow fall in north central Colorado: Or odd things that happen during severe droughts - A meteorologist's view. Colorado Climate: Water Year 2003, 4 (1-4), 1-2, 19-21. [Available online at ccc.atmos.colostate.edu/pdfs/ wy2003.pdf.] , 2004: Heavy snowfall...in the midst of a drought. Cooperative Institute for Research in the Atmosphere. 22, 8-13. [Available online at www.cira.colostate.edu/ publications/newsletter/fall2004.pdf.]

Wesley, D. A., R. M. Rasmussen, and B. C. Bernstein, 1995: Snowfall associated with a terrain-generated convergence zone during the Winter Icing and Storm Project. Mon. Wea. Rev., 123, 2957-2977.

Wilson, W. E., 2003: Colorado is snowbound - the Great Front Range blizzard of 1913 (and its 2003 counterpart). Colorado Heritage, Autumn 2003, Colorado Historical Society, 1300 Broadway, Denver, CO 80203, 2-35. 